Original Research

\title{
Synthesis, characterization, and evaluation of antibacterial activity of transition metal oxyde nanoparticles
}

\author{
Dielly Oliveira Morais ${ }^{1} \cdot$ Alexandre Pancotti $^{1} \cdot$ Guilherme Sastre de Souza $^{1} \cdot$ Marielena Vogel Saivish $^{1}$. \\ Alexandre Braoios ${ }^{1} \cdot$ Marcos Lázaro Moreli ${ }^{1}$ Mauro Vinícius de B. Souza ${ }^{1}$ Vivaldo G. da Costa ${ }^{1} \cdot J_{i a l e ~ W a n g}{ }^{2}$
}

Received: 22 April 2021 / Accepted: 14 June 2021 / Published online: 18 August 2021

(c) The Author(s) 2021

\begin{abstract}
Nanoparticles (NPs) have a wide range of applications in various areas. For health application, cytotoxicity tests are used to ensure its efficiency and safety. In this paper, $\mathrm{ZnFe}_{2} \mathrm{O}_{4}, \mathrm{CoFe}_{2} \mathrm{O}_{4}, \mathrm{Zn}_{0.5} \mathrm{Co}_{0.5} \mathrm{Fe}_{2} \mathrm{O}_{4} \mathrm{NPs}$ were synthesized, characterized and their antibacterial properties were evaluated. The Sol-Gel method was used to synthesize the NPs. Their electronic and crystallographic structures were characterized by Fourier Transform Infrared Spectroscopy Analysis (FTIR), X-ray fluorescence (XRF), X-Ray Diffraction (XRD), and Transmission Electron Microscopy (TEM). To perform the antibacterial evaluation, ferrites were dispersed through nanoemulsion to prevent the crystals from accumulating together. Then the evaluation was performed through microdilution in a 96-well plate and diffusion in agar disc in contact with 3 different strains of Staphylococcus aureus and Escherichia coli. It demonstrated that the Sol-Gel method was efficient to synthesize NPs with suitable sizes for health application. All synthesized NPs showed the inhibition of bacterias with different concentrations used.
\end{abstract}

\section{Graphical Abstract}

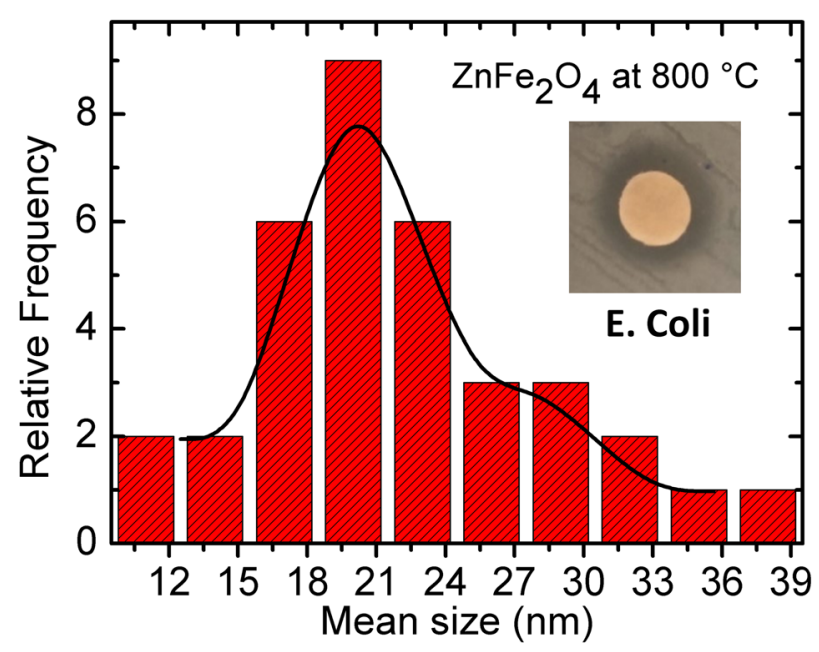

\section{Introduction}

Alexandre Pancotti apancotti@ufg.br

$\triangle$ Jiale Wang jiale.wang@dhu.edu.cn

1 Universidade Federal de Jataí, Unidade Acadêmica Especial de Ciências Exatas, Rod. Br 364, km 168, Jataí, GO, Brazil

2 College of Science, Donghua University, Shanghai 201620, China
Nanotechnology is commonly known as a multidisciplinary science, involving the physical, chemical, and biological areas, where important applications are widely observed, such as in the industrial sector and in medicine [1]. The biological use of nanoscale materials, also known as nanoparticles (NPs), can be studied both in in vitro and in vivo $[2,3]$. Various applications of NPs are related to the optical properties, size, shape, surface aspects, etc [4]. 
Because of their small size, unique physical-chemical characteristics have been observed [5]. Some NPs present magnetic characters that are composed of transition metals oxides, presenting the formula of $\mathrm{MFe}_{2} \mathrm{O}_{4}$, where $\mathrm{M}$ is a divalent metal, such as cobalt $\left(\mathrm{CoFe}_{2} \mathrm{O}_{4}\right)$ and zinc $\left(\mathrm{ZnFe}_{2} \mathrm{O}_{4}\right)$ [6-8]. Ferrites can be synthesized by multiple methods, i.e., solid-state reaction [9], polymeric precursors [10], thermal decomposition [11], hydrothermal [12], etc. The polymeric precursor method involves a sol-gel process, which starts with precursors in the liquid state, followed by the formation of the sol phase, which is a colloidal suspension. For the gel phase, organic precursors that have a chelating function are usually used, which may be citrate, gelatin, etc. And then the final product is calcined to form stable and homogeneous crystalline structures [10].

The incessant search for new antimicrobial drugs is due to the large number of microorganisms resistant to conventional antimicrobials [13], where NPs are considered as one of the alternatives. The activities provided by metal ions in biological environments have stimulated the research and development of these compounds as therapeutic agents in the treatment of infectious diseases [14]. Ag NPs accumulated in bacterial membrane can cause perforations in the membrane and result in the death of cell [15]. Ferrite NPs have an important role against Gram-positive and Gramnegative bacteria, suggesting that they can be used as antibacterial agents [16]. Ferrites NPs have efficient antibacterial properties against different bacterias.

Some properties of NPs can influence nanotoxicity. Lima et al. [17] demonstrated that the smaller the size, the greater the effect of cell uptake and toxicity. The charge, composition, and morphology are important factors related to the interaction of these materials with cellular components. Other factors such as physical-chemical characteristics, crystalline structure, solubility, and agglomeration are related to the mechanisms of action that cause toxicity $[18,19]$.

\section{Experimental}

\subsection{Materials and methods}

Metal salts of iron nitrate $\left(\mathrm{Fe}\left(\mathrm{NO}_{3}\right)_{3} \cdot 9 \mathrm{H}_{2} \mathrm{O}\right)$, cobalt nitrate $\left(\mathrm{Co}\left(\mathrm{NO}_{3}\right)_{2} \cdot 6 \mathrm{H}_{2} \mathrm{O}\right)$, zinc nitrate $\left(\mathrm{Zn}\left(\mathrm{NO}_{3}\right)_{2} \cdot 6 \mathrm{H}_{2} \mathrm{O}\right)$, colorless gelatin, $5 \%$ citric acid, and $35 \%$ hydrogen peroxide $\left(\mathrm{H}_{2} \mathrm{O}_{2}\right)$ (Sigma-Aldrich) were used. Mineral oil, tween 80 (Polysorbate 80 ), and propylene glycol were used for dispersion. In antibacterial tests, Mueller-Hinton (MH) broth and agar were used. And in the cytotoxic tests, MEM medium + $10 \%$ fetal bovine serum $(\mathrm{FBS})+$ gentamicin $(50 \mu \mathrm{g} / \mathrm{mL})$, penicillin (100 IU/mL), amphotericin B $(5 \mu \mathrm{g} / \mathrm{mL})$, MTT, and DMSO were used.

\subsection{Preparation of $\mathrm{ZnFe}_{2} \mathrm{O}_{4}$ and $\mathrm{CoFe}_{2} \mathrm{O}_{4} \mathrm{NPs}$}

The $\mathrm{ZnFe}_{2} \mathrm{O}_{4}$ and $\mathrm{CoFe}_{2} \mathrm{O}_{4}$ ferrite NPs were synthesized by using the sol-gel method, with a molar ratio of 1:2 $(\mathrm{Co}: \mathrm{Fe}$ or $\mathrm{Zn}: \mathrm{Fe})$. To obtain the cobalt ferrite, $20.655 \mathrm{~g}$ of $\mathrm{Fe}\left(\mathrm{NO}_{3}\right)$ ${ }_{3} \cdot 9 \mathrm{H}_{2} \mathrm{O}$ and $7.44 \mathrm{~g}$ of $\mathrm{Co}\left(\mathrm{NO}_{3}\right)_{2} \cdot 6 \mathrm{H}_{2} \mathrm{O}$ were used. To obtain zinc ferrite, $20.655 \mathrm{~g} \mathrm{Fe}\left(\mathrm{NO}_{3}\right)_{3} \cdot 9 \mathrm{H}_{2} \mathrm{O}$ and $7.40 \mathrm{~g}$ of $\mathrm{Zn}$ $\left(\mathrm{NO}_{3}\right)_{2} \cdot 6 \mathrm{H}_{2} \mathrm{O}$ were weighed. Each salt was added, separately, in $90 \mathrm{~mL}$ of distilled water. In another 4 containers, $10.341 \mathrm{~g}$ of colorless gelatin was added in $90 \mathrm{ml}$ of distilled water. The metal salts and gelatine were kept under constant stirring and heating at $40^{\circ} \mathrm{C}$ for $40 \mathrm{~min}$. After complete dissolution, gelatin and each nitrate were mixed separately, keeping under constant stirring and heating. And then cobalt nitrate was mixed with the solution. Finally, the solution was placed in a drying and sterilization oven at a temperature of $100{ }^{\circ} \mathrm{C}$ for $24 \mathrm{~h}$ to evaporate the water. The dry samples formed the xerogel and they were macerated until the formation of a homogeneous powder. The powders were calcined in a tubular oven at 250 and $800^{\circ} \mathrm{C}$ for $4 \mathrm{~h}$, with a heating rate maintained at $4{ }^{\circ} \mathrm{C} / \mathrm{min}$. Finally, the removal of residual organic matter was carried out by chemical treatment with $35 \% \quad \mathrm{H}_{2} \mathrm{O}_{2}$. The samples were washed with distilled water, followed by centrifugation, to separate the supernatant during synthesis. In the end, the samples were dried at $100{ }^{\circ} \mathrm{C}$ for $24 \mathrm{~h}$ [17].

\subsection{Preparation of NP $\mathrm{Zn}_{0.5} \mathrm{Co}_{0.5} \mathrm{Fe}_{2} \mathrm{O}_{4}$}

$\mathrm{Co}^{2+}$ substituted zinc ferrite $\mathrm{Zn}_{0.5} \mathrm{Co}_{0.5} \mathrm{Fe}_{2} \mathrm{O}_{4}$ NPs was synthesized via polymeric precursor with $5 \%$ wt citric acid. The molar ratio of $\mathrm{Zn}: \mathrm{Co}: \mathrm{Fe}$ was $0.5: 0.5: 2$, where $16.97 \mathrm{~g}$ $\mathrm{Fe}\left(\mathrm{NO}_{3}\right)_{3} \cdot 9 \mathrm{H}_{2} \mathrm{O}, 3.05 \mathrm{~g} \mathrm{Co}\left(\mathrm{NO}_{3}\right)_{2} \cdot 6 \mathrm{H}_{2} \mathrm{O}$, and $3.12 \mathrm{~g} \mathrm{Zn}$ $\left(\mathrm{NO}_{3}\right)_{2} \cdot 6 \mathrm{H}_{2} \mathrm{O}$ were used, respectively. Each kind of salt was dissolved individually in a beaker with citric acid and kept under stirring at $70^{\circ} \mathrm{C}$ for $40 \mathrm{~min}$. And then they were mixed in a container and placed in an oven, drying at $100{ }^{\circ} \mathrm{C}$ for $12 \mathrm{~h}$ [20].

\subsection{Characterization studies}

In order to characterize the structures of ferrites, Fourier transform infrared (FTIR) spectroscopy and X-ray fluorescence (XRF) were used. To perform the FTIR, the sample was placed in a JASCO FTIR-4100 sample holder. Data acquisition was performed in the range of $400-4000 \mathrm{~cm}^{-1}$ with a step of $0.01 \mathrm{~cm}^{-1}$. XRF was carried out on a Shimadzu model EDX-720. The measurements were performed in the range of $0-50 \mathrm{keV}$ with a step of $0.01 \mathrm{keV}$. The experiments were performed at a pressure of $2.0 \times 10^{-8}$ mbar. The XPS spectra were collected using a conventional $\mathrm{Al} \mathrm{K}_{\alpha} \mathrm{X}$-rays source with photon energy of $1486.6 \mathrm{eV}$. A VSW HA100 electron analyzer was used with $44 \mathrm{eV}$ pass 
energy and $0.1 \mathrm{eV}$ step. The base pressure in the analysis chamber was less than $5.0 \times 10^{-9} \mathrm{mbar}$. The binding energy (BE) scale was ajusted using the $\mathrm{C} 1 s$ line at $284.6 \mathrm{eV}$ as a reference. A $10^{\circ}$ takeoff angle was used to increase the surface sensitivity of the core-level peaks. The data were analyzed using the Winspec software. Shirley backgrounds were subtracted from the experimental data results.

XRD was performed with a Rigaku X-ray Diffractometer. The samples were analyzed using the diffractometer with the following parameters: voltage of $40 \mathrm{kV}$, current of $20 \mathrm{~mA}$, low incidence angle of $10^{\circ}, \theta-2 \theta$ mode scan, range of $20-70^{\circ}$, scanning rate of $0.5^{\circ} / \mathrm{min}$, and $\mathrm{Cu} \mathrm{K}_{\alpha}(\lambda=1.541 \AA)$ as source.

TEM was performed in a JEOL transmission electron microscope (JEM-2100) equipped with Thermoscientific EDS. The analyzed samples were prepared by adding $1 \mathrm{mg}$ of the powder in an Eppendorf, where ethanol was used as a dispersing solvent and was placed in an ultrasound bath for $15 \mathrm{~min}$. After dispersion, $250 \mu \mathrm{L}$ of each sample was placed on the copper grid and rested on filter paper for ethanol evaporation. Then it was fitted in the microscope sample holder. The acceleration voltage used was $200.0 \mathrm{kV}$.

\subsection{Dispersion of ferrites}

Nanoemulsion composed by mineral oil, tween 80, propylene glycol, and water were used in the proportion of 1:1:2:6 to form a stable dispersion of ferrites in an aqueous medium. Each component was sterilized by autoclaving, filtration, and ultraviolet radiation.

\subsection{Antibacterial tests}

To perform the antibacterial tests, two methods were used: minimum inhibitory concentration (MIC) and disk diffusion on agar. Both tests were performed on three different strains of two species of bacteria: Gram-positive, Staphylococcus aureus ATCC (American Type Culture Collection) 25923, 29213, and 43300, as well as Gram-negative, Escherichia coli ATCC 25922, 51446, and 35218. Each strain was diluted in a saline solution, which was at the MacFarland scale $0.5, \sim 1.5 \times 10^{8} \mathrm{UFC} / \mathrm{mL}$ [21].

The MIC method was performed to determine the lowest concentration capable of inhibiting the proliferation of the tested microorganisms. Thus, the NPs and strains were diluted in the following concentrations: $1 \mathrm{mg} / \mathrm{mL}, 0.5 \mathrm{mg} /$ $\mathrm{mL}$ and $0.25 \mathrm{mg} / \mathrm{mL}$. The tests were performed using 96well plates with a "flat" bottom and in triplicate for each concentration of ferrite in MH broth. Three different types of inhibition controls were carried out. The positive inhibition controls were composed by Penicillin G Potassium at $10,000 \mathrm{UI} / \mathrm{mL}$, and streptomycin sulfate at $10 \mathrm{mg} / \mathrm{mL}$. The negative control was realized without the addition of microorganism. The microplates were incubated in an oven at $37^{\circ} \mathrm{C}$ for $72 \mathrm{~h}$. The microplate spectrophotometer was used to read the optical density, using the $630 \mathrm{~nm}$ primary filter, in the periods of 24,48 , and $72 \mathrm{~h} \mathrm{[22].}$

The disk diffusion test was realized according to the Kirby-Bauer Method. The inoculum of the microorganism was seeded over the entire surface of MH agar in a Petri disc. Then the NPs of $2 \mathrm{mg} / \mathrm{mL}$ were deposited on the agar surface. The plates were incubated in an oven at $37^{\circ} \mathrm{C}$ for $24 \mathrm{~h}$. The results were analyzed according to the presence or absence of a growth inhibition halo around the discs [20, 23-25].

\subsection{Determination of cell viability}

The cytotoxicity of NPs was assessed by MTT assay. Briefly, Vero cells at a density of $1 \times 10^{5}$ cells $/ \mathrm{mL}$ were seeded in a flat-bottomed 96 -well microtiter plate (KasviBrazil) and were incubated for $24 \mathrm{~h}$ at $37^{\circ} \mathrm{C}$ and $5 \% \mathrm{CO}_{2}$, supplemented with $10 \%$ heat-inactivated FBS (Invitrogen, USA), $2 \mathrm{mM}$ L-glutamine (Merck, Germany), and $100 \mathrm{U} / \mathrm{ml}$ penicillin and $100 \mu \mathrm{g} / \mathrm{ml}$ streptomycin sulfate (SigmaAldrich, USA). A range of concentrations from 62.5 to $1000 \mu \mathrm{g} / \mathrm{ml}$ of NPs was prepared using the cell culture medium DMEM and was added to the plate in triplicate. After $72 \mathrm{~h}$, the treatments were removed and $100 \mu \mathrm{L}$ of MTT reagent of concentration from $0.5 \mathrm{mg} / \mathrm{mL}$ in DMEM was added to each well and incubated for a further $2 \mathrm{~h}$. The medium was then removed and $100 \mu \mathrm{L}$ of DMSO solution was added to the wells. Finally, the plate was read at $550 \mathrm{~nm}$ by a microplate reader.

\section{Results and discussion}

\subsection{FTIR}

Figure 1 exhibits the typical FTIR spectrum of $\mathrm{ZnFe}_{2} \mathrm{O}_{4}$, $\mathrm{CoFe}_{2} \mathrm{O}_{4}$, and $\mathrm{Zn}_{0.5} \mathrm{Co}_{0.5} \mathrm{Fe}_{2} \mathrm{O}_{4}$ NPs calcined in two different temperatures, which exhibits various well-defined peaks. The spectrum a (b) shows the absorption peaks for $\mathrm{ZnFe}_{2} \mathrm{O}_{4}$ calcined at $250^{\circ} \mathrm{C}\left(800^{\circ} \mathrm{C}\right)$. The well-defined peaks at $423 \mathrm{~cm}^{-1}\left(417 \mathrm{~cm}^{-1}\right), \quad 590 \mathrm{~cm}^{-1}\left(563 \mathrm{~cm}^{-1}\right)$, $1098 \mathrm{~cm}^{-1}\left(1107 \mathrm{~cm}^{-1}\right), 1401 \mathrm{~cm}^{-1}\left(1398 \mathrm{~cm}^{-1}\right), 1645 \mathrm{~cm}$ ${ }^{-1}\left(1636 \mathrm{~cm}^{-1}\right)$, and $3448 \mathrm{~cm}^{-1}\left(3463 \mathrm{~cm}^{-1}\right)$ were associated with the chemical bonds between the atoms of $\mathrm{Fe}-\mathrm{O}$, $\mathrm{Zn}-\mathrm{O}, \mathrm{C}=\mathrm{O}, \mathrm{C}-\mathrm{H}, \mathrm{O}-\mathrm{H}$, and $\mathrm{O}-\mathrm{H}$, respectively [26].

The spectrum $\mathrm{c}$ (d) shows the absorption peaks for $\mathrm{CoFe}_{2} \mathrm{O}_{4}$ calcined at $250{ }^{\circ} \mathrm{C}\left(800^{\circ} \mathrm{C}\right)$. The peaks at $416 \mathrm{~cm}$ ${ }^{-1}\left(420 \mathrm{~cm}^{-1}\right), 592 \mathrm{~cm}^{-1}\left(587 \mathrm{~cm}^{-1}\right), 1120 \mathrm{~cm}^{-1}(1085 \mathrm{~cm}$ $\left.{ }^{-1}\right), 1398 \mathrm{~cm}^{-1}\left(1401 \mathrm{~cm}^{-1}\right), 1638 \mathrm{~cm}^{-1}\left(1628 \mathrm{~cm}^{-1}\right)$, and $3461 \mathrm{~cm}^{-1}\left(3442 \mathrm{~cm}^{-1}\right)$ were associated with the chemical 
bonds between the atoms of $\mathrm{Fe}-\mathrm{O}, \mathrm{Co}-\mathrm{O}$ or $\mathrm{Fe}-\mathrm{O}, \mathrm{C}=\mathrm{O}$, $\mathrm{C}-\mathrm{H}, \mathrm{O}-\mathrm{H}$, and $\mathrm{O}-\mathrm{H}$, respectively $[5,27,28]$.

The spectrum (f) shows the absorption peaks for $\mathrm{Zn}_{0.5} \mathrm{Co}_{0.5} \mathrm{Fe}_{2} \mathrm{O}_{4}$ NPs calcined at $250{ }^{\circ} \mathrm{C}\left(800^{\circ} \mathrm{C}\right)$. The peaks at $412 \mathrm{~cm}^{-1}\left(418 \mathrm{~cm}^{-1}\right), 583 \mathrm{~cm}^{-1}\left(575 \mathrm{~cm}^{-1}\right)$, $1090 \mathrm{~cm}^{-1}\left(1086 \mathrm{~cm}^{-1}\right), 1403 \mathrm{~cm}^{-1}\left(1395 \mathrm{~cm}^{-1}\right), 1635 \mathrm{~cm}$ ${ }^{-1}\left(1643 \mathrm{~cm}^{-1}\right)$, and $3437 \mathrm{~cm}^{-1}\left(3465 \mathrm{~cm}^{-1}\right)$ were associated with the chemical bonds between the atoms of $\mathrm{Fe}-\mathrm{O}$, $\mathrm{Fe}-\mathrm{O}$ or $\mathrm{Zn}-\mathrm{O}$ or $\mathrm{Co}-\mathrm{O}, \mathrm{C}=\mathrm{O}, \mathrm{OH}, \mathrm{OH}$, and $\mathrm{OH}$, respectively. The first two peaks were attributed to the metal-oxygen bonds $(\mathrm{Fe}-\mathrm{O})$ in the tetrahedral sites, and the second peak was associated to the metal-oxygen bonds $(\mathrm{Fe}-\mathrm{O}, \mathrm{Zn}-\mathrm{O}$, and $\mathrm{Co}-\mathrm{O})$ in the octahedral sites. This is the typical characteristic of the reverse spinel and normal spinel

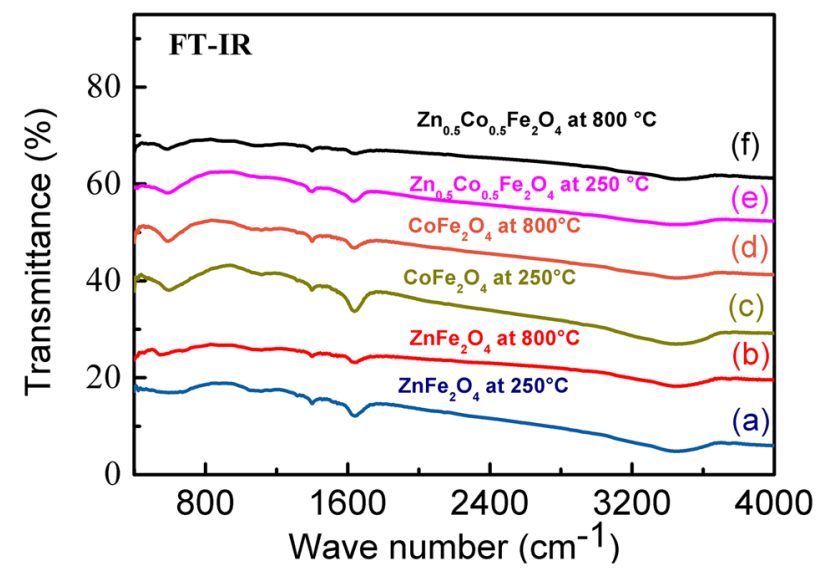

Fig. 1 Typical FTIR spectrum of calcinated nanoparticles. FTIR spectroscopy of a, b $\mathrm{ZnFe}_{2} \mathrm{O}_{4}$, c, $\mathbf{d ~ C o F e} \mathrm{O}_{4}$, and e, $\mathbf{f} \mathrm{Zn}_{0.5} \mathrm{Co}_{0.5} \mathrm{Fe}_{2} \mathrm{O}_{4}$ calcined at 250 and $800{ }^{\circ} \mathrm{C}$ for $\mathrm{Co}^{2+}$ substituted zinc ferrite $\mathrm{Zn}_{0.5} \mathrm{Co}_{0.5} \mathrm{Fe}_{2} \mathrm{O}_{4}$, magnetic NPs [27, 29-31].

\subsection{XRF}

Figure 2 shows the XRF spectra for the $\mathrm{ZnFe}_{2} \mathrm{O}_{4}$ and $\mathrm{CoFe}_{2} \mathrm{O}_{4} \mathrm{NPs}$ calcined at different temperatures. In the Fig. 2a, b, the components present at $6.2 \mathrm{keV}$ and $7.1 \mathrm{keV}$ correspond to $K_{\alpha}$ and $K_{\beta}$ lines of $\mathrm{Fe}$ atom. The components present at 8.6 and $9.5 \mathrm{keV}$ are due to $\mathrm{K}_{\alpha}$ and $\mathrm{K}_{\beta}$ lines of $\mathrm{Zn}$ atom. In Fig. 2c, d, the components present at $6.9 \mathrm{keV}$ corresponds to $K_{\alpha}$ and $K_{\beta}$ line of Co atom. The average chemical composition obtained for $\mathrm{ZnFe}_{2} \mathrm{O}_{4}$ is $65.5 \%$-wt (66.4\%-wt) Fe, 29.8\%-wt (30.6\%-wt) $\mathrm{Zn}$ for $\mathrm{ZnFe}_{2} \mathrm{O}_{4}$ calcined at $250{ }^{\circ} \mathrm{C}\left(800^{\circ} \mathrm{C}\right)$. Meanwhile, the average chemical composition obtained for $\mathrm{CoFe}_{2} \mathrm{O}_{4}$ are $72.0 \%$-wt $(72.1 \%$ wt) $\mathrm{Fe}, 26.5 \%$-wt $\left(26.8 \%\right.$-wt) $\mathrm{Co}$ for $\mathrm{CoFe}_{2} \mathrm{O}_{4}$ calcined at $250^{\circ} \mathrm{C}\left(800^{\circ} \mathrm{C}\right)$.

\subsection{XPS}

Wide-energy range XPS (survey) spectra were collected for assessing the cleanliness state of the NPs calcined at $800{ }^{\circ} \mathrm{C}$ are shown in Fig. 3. The atomic ratios determined by XPS are consistent with the $\mathrm{CoFe}_{2} \mathrm{O}_{4}$ and $\mathrm{ZnFe}_{2} \mathrm{O}_{4}$ NPs stoichiometry. There had been a significant amount of carbon at the surface, which was reduced by the calcination. The $\mathrm{C} 1 \mathrm{~s}$ peak at $284.6 \mathrm{eV}$ was used as a reference BE for calibration.

Figure $3 \mathrm{~b}$ shows the measured HRXPS (high-resolution XPS) spectra of zinc ferrite NPs. Deconvolution of the $\mathrm{Zn}$ $2 p_{3 / 2}$ peak was performed in the $\mathrm{Zn} 2 p$ spectra as shown in Fig. 3b. The peak at $1021.4 \mathrm{eV}$ was associated to $\mathrm{Zn}^{2+}$
Fig. 2 XRF spectra for the $\mathbf{a}, \mathbf{b}$ $\mathrm{ZnFe}_{2} \mathrm{O}_{4}$ and $\mathbf{c}, \mathbf{d ~} \mathrm{CoFe}_{2} \mathrm{O}_{4}$ NPs calcined at $250{ }^{\circ} \mathrm{C}$ and $800{ }^{\circ} \mathrm{C}$

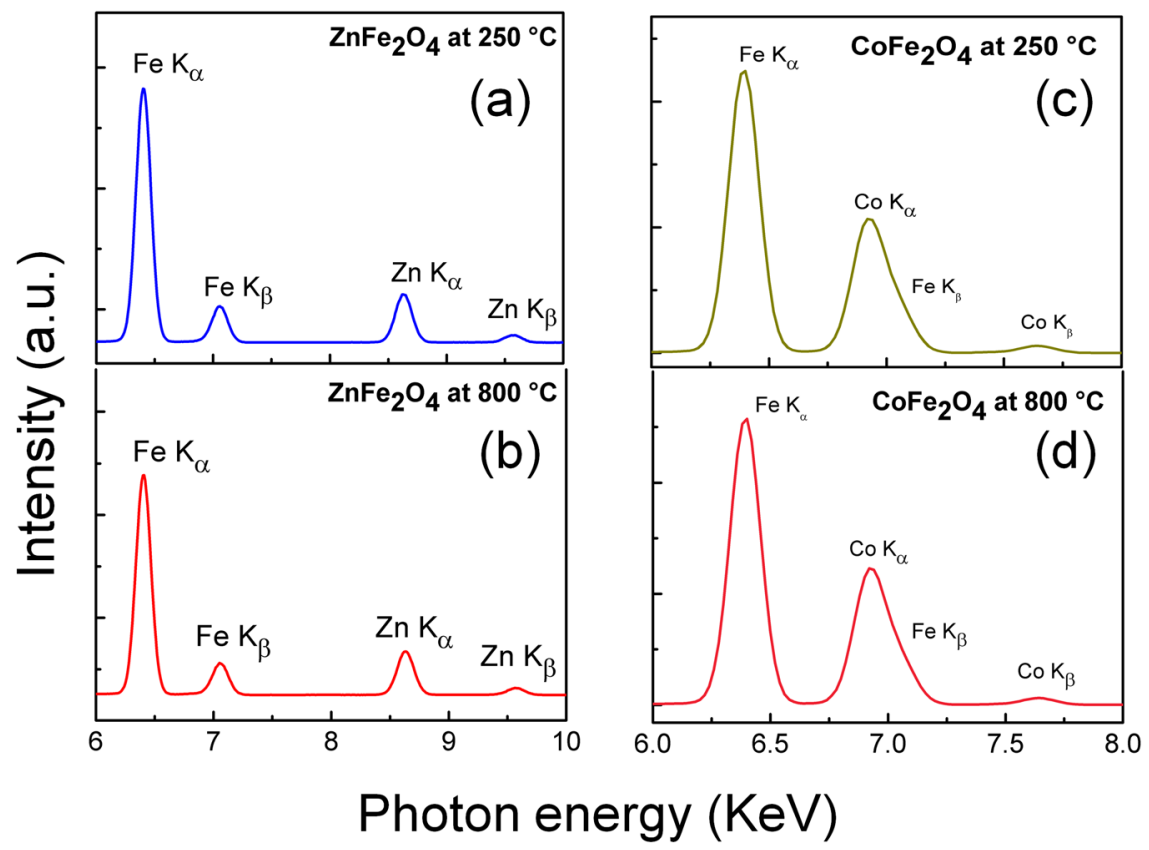



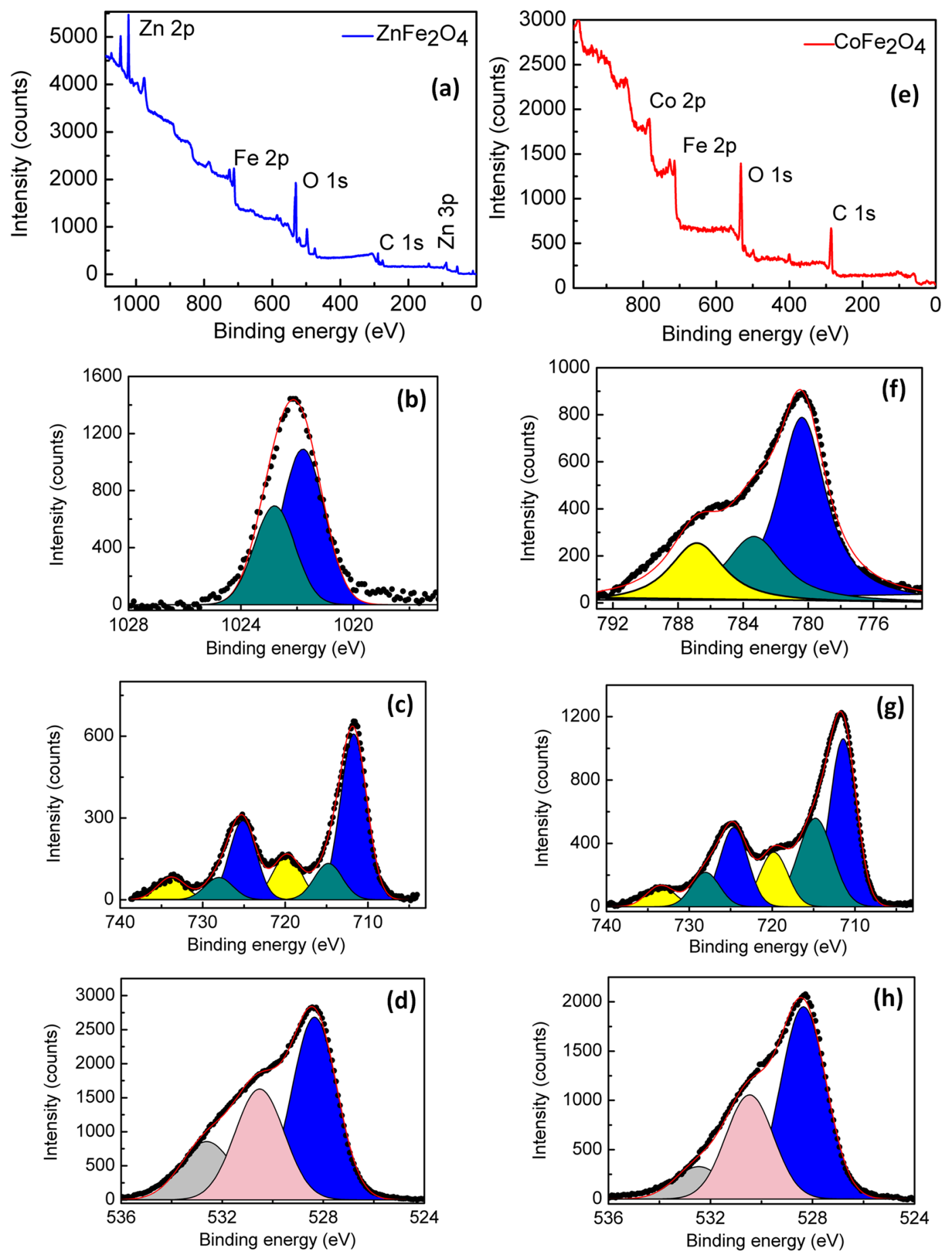

Fig. 3 Survey XPS spectra for the $\mathbf{a} \mathrm{ZnFe}_{2} \mathrm{O}_{4}$ and $\mathbf{e ~} \mathrm{CoFe}_{2} \mathrm{O}_{4} \mathrm{NPs}$ calcined at $800{ }^{\circ} \mathrm{C}$. HRXPS for $\mathrm{Zn}$ ferrite nanoparticles calcined at $800{ }^{\circ} \mathrm{C}$ for: $\mathbf{b} \mathrm{Zn}$ $2 p$; c Fe $2 p$; d O1s. HRXPS for Co ferrite nanoparticles calcined at $800^{\circ} \mathrm{C}$ for: $\mathbf{f} \mathrm{Co} 2 p ; \mathbf{g} \mathrm{Fe} 2 p$; h O1s

occupying tetrahedral sites and the peak at $1022.6 \mathrm{eV}$ was associated to $\mathrm{Zn}^{2+}$ occupying octahedral sites in zinc ferrite [32].

Figure $3 c$ shows the Fe $2 p$ core-level of $\mathrm{ZnFe}_{2} \mathrm{O}_{4} \mathrm{NPs}$ calcined at $800^{\circ} \mathrm{C}$. The XPS spectrum has three components. The $\mathrm{BE}$ of $711.7 \mathrm{eV}\left(\mathrm{Fe} 2 p_{3 / 2}\right)$ and $725.1 \mathrm{eV}\left(\mathrm{Fe} 2 p_{1 /}\right.$ 2) was associated to $\mathrm{Fe}^{3+}$ ions in octahedral site, with corresponding satellite peaks at $719.8 \mathrm{eV}\left(\mathrm{Fe} 2 p_{3 / 2}\right)$ and $733.8 \mathrm{eV}\left(\mathrm{Fe} 2 p_{1 / 2}\right)$, respectively. The BE of $714.8 \mathrm{eV}$ and $728.0 \mathrm{eV}$, was related to $\mathrm{Fe}^{3+}$ ions in tetrahedral sites in $\mathrm{Zn}$ ferrite NPs [32].

Figure $3 \mathrm{~d}$ shows the XPS for $\mathrm{O} 1 s$ core-level of $\mathrm{ZnFe}_{2} \mathrm{O}_{4}$ NPs calcined at $800{ }^{\circ} \mathrm{C}$. This spectrum is formed by three components presents at 528.3, 530.5, and $532.6 \mathrm{eV}$. The 


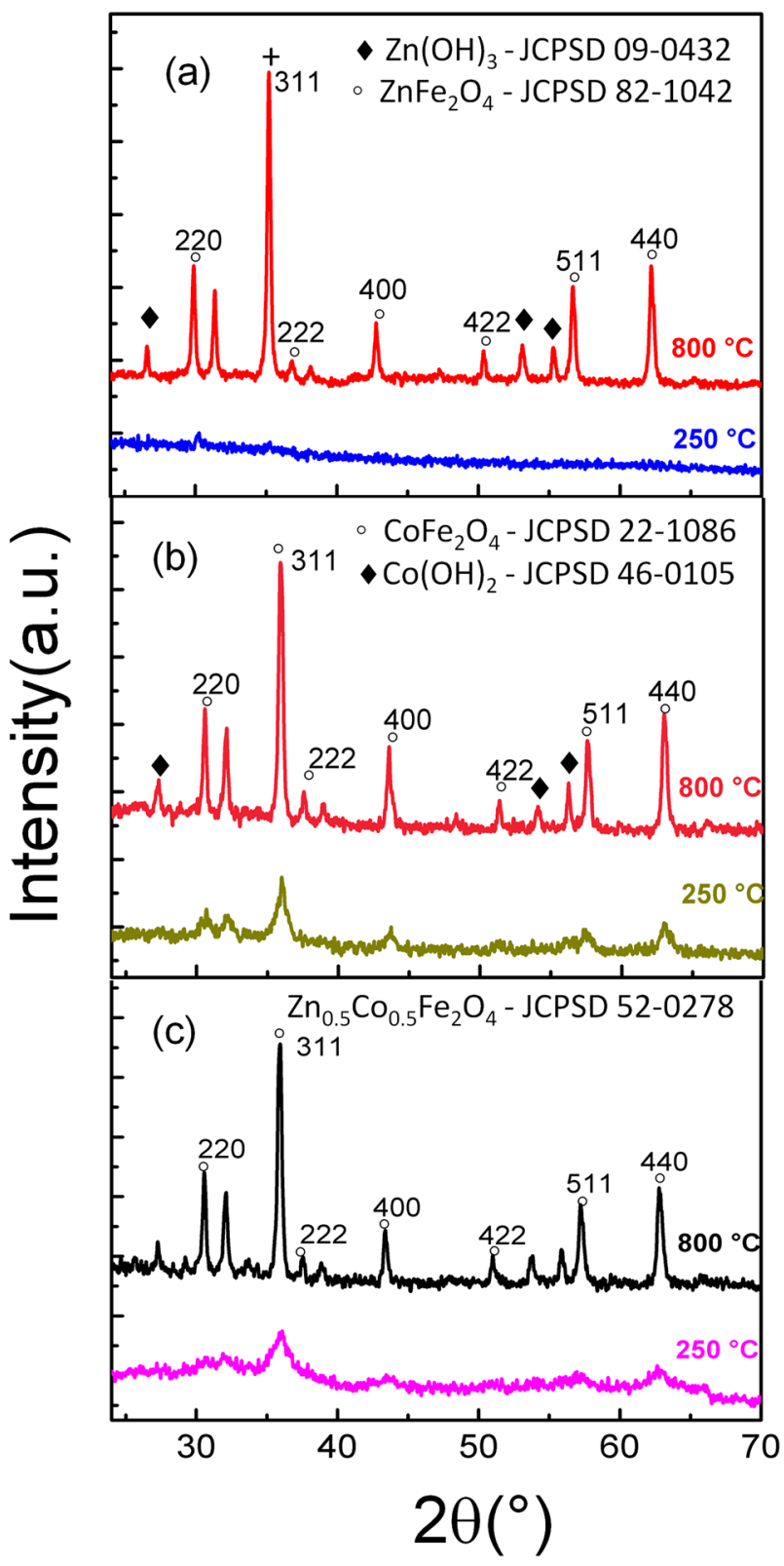

Fig. $4 \mathrm{X}$-ray diffraction diffractograms for the $\mathrm{ZnFe}_{2} \mathrm{O}_{4}(\mathbf{a}), \mathrm{CoFe}_{2} \mathrm{O}_{4}$ (b) and $\mathrm{Zn}_{0.5} \mathrm{Co}_{0.5} \mathrm{Fe}_{2} \mathrm{O}_{4}$ (c) NPs calcinated at 250 and $800{ }^{\circ} \mathrm{C}$

component present at $528.3 \mathrm{eV}$ was associated to oxygen of $\mathrm{ZnFe}_{2} \mathrm{O}_{4} \mathrm{NPs}$ and the components at $530.5 \mathrm{eV}$ and 532.6 were associates to carbonate or hydroxyl groups chemically bound to surface cations of NPs [33-35].

Figure $3 \mathrm{f}$ shows the XPS spectra of Co $2 p_{3 / 2}$ core-level calcined at $800{ }^{\circ} \mathrm{C}$, which has three components with BE of $780.3,783.3$, and 787.3 , and $783.3 \mathrm{eV}$ were associated to $\mathrm{Co}^{2+}$ ions in the octahedral and tetrahedral sites [36, 37]. The peak at $787.3 \mathrm{eV}$ was associated to the shake-up satellite peak of Co $2 p_{3 / 2}$ main line [36].

Figure $3 \mathrm{~g}$ shows the $\mathrm{Fe} 2 p$ core-level of $\mathrm{CoFe}_{2} \mathrm{O}_{4} \mathrm{NPs}$ calcined at $800^{\circ} \mathrm{C}$. The XPS spectrum has 3 components. The $\mathrm{BE}$ of $711.4 \mathrm{eV}\left(\mathrm{Fe} 2 p_{3 / 2}\right)$ and $724.6 \mathrm{eV}\left(\mathrm{Fe} \mathrm{2} p_{1 / 2}\right)$ refers to the $\mathrm{Fe}^{3+}$ ions in octahedral site, with corresponding satellite peaks at $719.8 \mathrm{eV}\left(\mathrm{Fe} 2 p_{3 / 2}\right)$ and $733.4 \mathrm{eV}\left(\mathrm{Fe} 2 p_{1 /}\right.$ 2), respectively. The $\mathrm{BE}$ of $714.8 \mathrm{eV}$ and $728.0 \mathrm{eV}$, was associated to $\mathrm{Fe}^{3+}$ ions in tetrahedral sites.

The asymmetrical complex peak of the O $1 s$ XPS spectrum (Fig. 3h) can be decomposed into three components, with $\mathrm{BE}$ of $528.3,530.5$, and $532.6 \mathrm{eV}$. Similar to the $\mathrm{ZnFe}_{2} \mathrm{O}_{4}$ NPs mention previously, the component present at $528.3 \mathrm{eV}$ was related to oxygen of bulk structure and the components at 530.5 and $532.6 \mathrm{eV}$ were associates to carbonate or hydroxyl groups chemically bound to surface cations of NPs [32, 38]. These XPS results are in perfect agreement with the XRD measurements.

\subsection{XRD}

Figure 4a shows the XRD diffractograms of $\mathrm{ZnFe}_{2} \mathrm{O}_{4}$ NPs calcined at 250 and $800^{\circ} \mathrm{C}$. There were no diffraction peaks in the angular range acquired for the $\mathrm{ZnFe}_{2} \mathrm{O}_{4}$ calcined at $250^{\circ} \mathrm{C}$, demonstrating its amorphous characteristic. For the $\mathrm{ZnFe}_{2} \mathrm{O}_{4} \mathrm{NPs}$ calcined at $800^{\circ} \mathrm{C}$, the peaks at $30^{\circ}, 35^{\circ}, 37^{\circ}$, $43^{\circ}, 52^{\circ}, 57^{\circ}$, and $62^{\circ}$ were associated to (220), (311), (222), (400), (422), (511) and (440) facet, respectively.

Figure $4 \mathrm{~b}$ shows the XRD diffractograms of $\mathrm{CoFe}_{2} \mathrm{O}_{4}$ NPs calcined at $250^{\circ} \mathrm{C}$ and 800 . For the sample calcined at $250^{\circ} \mathrm{C}$, the diffraction peaks at $32^{\circ}, 36^{\circ}, 43^{\circ}, 52^{\circ}, 57^{\circ}$, and $63^{\circ}$ were associated to (220), (311), (400), (422), (511), and (440) facet, respectively. For the sample calcined at $800^{\circ} \mathrm{C}$, the diffraction peaks at $32^{\circ}, 36^{\circ}, 37^{\circ}, 43^{\circ}, 52^{\circ}, 57^{\circ}$, and $63^{\circ}$ were associated to (220), (311), (222), (400), (422), (511), and (440) facet, respectively. The change of the width in diffraction peaks suggested that NPs calcined at high temperatures have a larger size, as shown in the Table 1.

Figure 4c shows the XRD diffractograms of $\mathrm{Zn}_{0.5} \mathrm{Co}_{0.5^{-}}$ $\mathrm{Fe}_{2} \mathrm{O}_{4} \mathrm{NPs}$ calcined at 250 and $800^{\circ} \mathrm{C}$. The diffraction peaks at $36^{\circ}, 43^{\circ}, 57^{\circ}$, and $63^{\circ}$ corresponds to (311), (400), (511), and (440) facet, respectively. For the sample calcined at $800^{\circ} \mathrm{C}$, the diffraction peaks at $30^{\circ}, 36^{\circ}, 37^{\circ}, 43^{\circ}, 52^{\circ}$, $57^{\circ}$, and $63^{\circ}$ were associated to (220), (311), (222), (400), (422), (511), and (440) facet, respectively. The change of the width in diffraction peaks also suggested that NPs calcined at high temperatures have a larger size, as shown in Table 1.

Table 1 shows the crystallites sizes for the synthesized NPs. The crystallites sizes were determined by Scherrer equation.

Table 1 shows that the crystallite sizes changed after the high-temperature calcination [35, 38] and showed that higher calcination temperatures produce higher intense peaks, increased grain size, and better crystallinity. These authors obtained 19 and $86 \mathrm{~nm}$ of cristallite size for zinc ferrite non-calcined and calcined for a longer time. Lima et al. [17] showed that the size of the NP has a great 
Table 1 Crystallite sizes (nm), where the $2 \theta$, were obtained from the XRD diffractograms

\begin{tabular}{|c|c|c|c|c|c|c|c|}
\hline \multicolumn{8}{|c|}{ Crystallite size - Scherrer equation (nm) } \\
\hline \multirow{2}{*}{$\begin{array}{l}\text { Bragg } \\
\text { angle } \\
(2 \theta)\end{array}$} & \multirow[t]{2}{*}{ Miller indice } & \multicolumn{6}{|l|}{ Ferrites } \\
\hline & & $\begin{array}{l}\mathrm{ZnFe}_{2} \mathrm{O}_{4} \\
\text { at } 250^{\circ} \mathrm{C}\end{array}$ & $\begin{array}{l}\mathrm{ZnFe}_{2} \mathrm{O}_{4} \\
\text { at } 800^{\circ} \mathrm{C}\end{array}$ & $\begin{array}{l}\mathrm{CoFe}_{2} \mathrm{O}_{4} \\
\text { at } 250^{\circ} \mathrm{C}\end{array}$ & $\begin{array}{l}\mathrm{CoFe}_{2} \mathrm{O}_{4} \\
\text { at } 800{ }^{\circ} \mathrm{C}\end{array}$ & $\begin{array}{l}\mathrm{Zn}_{0.5} \mathrm{Co}_{0.5} \mathrm{Fe}_{2} \mathrm{O}_{4} \\
\text { at } 250{ }^{\circ} \mathrm{C}\end{array}$ & $\begin{array}{l}\mathrm{Zn}_{0.5} \mathrm{Co}_{0.5} \mathrm{Fe}_{2} \mathrm{O}_{4} \\
\text { at } 800^{\circ} \mathrm{C}\end{array}$ \\
\hline $30^{\circ}$ & 220 & - & 32.2 & 14.4 & 33.9 & - & 34.7 \\
\hline $36^{\circ}$ & 311 & - & 35.9 & 17.1 & 25.4 & 9.3 & 29.6 \\
\hline $37^{\circ}$ & 222 & - & 27.2 & - & 35.9 & - & 30.1 \\
\hline $43^{\circ}$ & 400 & - & 41.3 & 26.5 & 45.9 & - & 34.8 \\
\hline $52^{\circ}$ & 422 & - & 43.8 & - & 42.0 & - & 38.9 \\
\hline $57^{\circ}$ & 511 & - & 41.1 & 25.2 & 38.8 & - & 38.2 \\
\hline $62^{\circ}$ & 440 & - & 45.7 & 22.3 & 44.7 & 13.6 & 44.2 \\
\hline
\end{tabular}

We have used the constant $k=0.91$ and $\lambda=1.54 \AA$ in the Scherrer Equation influence on cytotoxicity, where Co NPs produced using the sol-gel method, have greater cytotoxic power when low calcination temperatures are performed. Figueiredo et al. [39], measured the cristallites size equal to 12, 10, and $10 \mathrm{~nm}$ for zinc, cobalt, and mixed ferrites synthesized using the combustion reaction technique, without undergoing by calcination treatment.

\subsection{TEM}

Figure 5 shows the TEM images of the $\mathrm{ZnFe}_{2} \mathrm{O}_{4}, \mathrm{CoFe}_{2} \mathrm{O}_{4}$, and $\mathrm{Zn}_{0.5} \mathrm{Co}_{0.5} \mathrm{Fe}_{2} \mathrm{O}_{4} \mathrm{NPs}$ calcined at different temperatures. Their corresponding size histograms are depicted in Fig. 6, which were elaborated from the frequency sizes from the measurement of NPs by using Image $\mathbf{J}$ software. To obtain the histogram a total of $N=50$ different particles sizes were used. Subsequently, a particle size histogram was mounted using the Sturges method [40]. The width (W) was obtained from the relation: $\mathrm{W}=(\operatorname{Dmax}-\mathrm{Dmin}) / k$, where $k=1+$ $3.322 \log (\mathrm{N})$. The histogram is fairly well modeled by a log-normal distribution, as shown in Fig. 6 for all the NPs.

$\mathrm{ZnFe}_{2} \mathrm{O}_{4}$ sample calcined at $250^{\circ} \mathrm{C}$ (Fig. 5a) showed characteristics of amorphous material, with an average size of $10.4 \mathrm{~nm}$ (Fig. 5b). For $\mathrm{CoFe}_{2} \mathrm{O}_{4}$ NPs calcined at $250{ }^{\circ} \mathrm{C}$ shown in Fig. 5e were observed the formation of partial amorphous structures. The same behavior was observed in the XRD measurements. These TEM images indicate that the $\mathrm{CoFe}_{2} \mathrm{O}_{4}$ and $\mathrm{Zn}_{0.5} \mathrm{Co}_{0.5} \mathrm{Fe}_{2} \mathrm{O}_{4} \mathrm{NPs}$ calcined at $250{ }^{\circ} \mathrm{C}$ were relatively uniform, which were around 12.4 (Fig. 5f) and $9.2 \mathrm{~nm}$ (Fig. 5j) in diameter, respectively. The TEM images of $\mathrm{ZnFe}_{2} \mathrm{O}_{4}, \mathrm{CoFe}_{2} \mathrm{O}_{4}$, and $\mathrm{Zn}_{0.5} \mathrm{Co}_{0.5} \mathrm{Fe}_{2} \mathrm{O}_{4} \mathrm{NPs}$ that were calcined at $800{ }^{\circ} \mathrm{C}$ are shown in Fig. $5 \mathrm{c}, \mathrm{g}$, k respectively. Here, the NPs sizes were larger compared to that calcined at $250{ }^{\circ} \mathrm{C}$, which were around 21.9 (Fig. 5d), 36.7 (Fig. 5h), and $31.4 \mathrm{~nm}$ (Fig. 5l) for $\mathrm{ZnFe}_{2} \mathrm{O}_{4}, \mathrm{CoFe}_{2} \mathrm{O}_{4}$, and $\mathrm{Zn}_{0.5} \mathrm{Co}_{0.5} \mathrm{Fe}_{2} \mathrm{O}_{4}$ NPs, respectively.

\subsection{Antibacterial tests}

Inhibition tests using the MIC method showed, for all ferrites, that the highest inhibitory concentration is greater than $1 \mathrm{mg} / \mathrm{mL}$. Thus, in Figs. 7 and 8 , show the results with the concentrations of $1 \mathrm{mg} / \mathrm{mL}, 0.5 \mathrm{mg} / \mathrm{mL}$, and $0.25 \mathrm{mg} / \mathrm{mL}$ according to the percentage of inhibition obtained using inhibition for the strains of $S$. aureus $(n=3)$ and E. coli $(n=3)$. This percentage was compared to the positive control for inhibition, which was a known antibiotic, and the negative control, which was the medium without the presence of inhibition. According to Fig. 7, the averages of inhibitions in the three incubation times are expressed for the ferrites calcined at $250{ }^{\circ} \mathrm{C}\left(800{ }^{\circ} \mathrm{C}\right)$ of $\mathrm{ZnFe}_{2} \mathrm{O}_{4}, \mathrm{CoFe}_{2} \mathrm{O}_{4}$, and $\mathrm{Zn}_{0.5} \mathrm{Co}_{0.5^{-}}$ $\mathrm{Fe}_{2} \mathrm{O}_{4}$ in contact with the strains of $S$. aureus $(n=3)$. For $\mathrm{ZnFe}_{2} \mathrm{O}_{4}$ ferrite calcined at $250{ }^{\circ} \mathrm{C}$ they were $67.5 \%$, $60.3 \%$, and $57.2 \%$, for $24 \mathrm{~h}, 48 \mathrm{~h}$ and $72 \mathrm{~h}$, respectively. And the averages for $\mathrm{ZnFe}_{2} \mathrm{O}_{4}$ calcined at $800{ }^{\circ} \mathrm{C}$ were $64.7 \%, 57.5 \%$, and $53.5 \%$, respectively, for the three incubation times. For the $\mathrm{CoFe}_{2} \mathrm{O}_{4}$ calcined at $250{ }^{\circ} \mathrm{C}$ ferrite, the growth inhibition averages obtained, in the incubation times equal to 24,48 , and $72 \mathrm{~h}$, were equal to $52.7 \%, 48.8 \%$, and $44.1 \%$, respectively. And for Co $\mathrm{Fe}_{2} \mathrm{O}_{4}$ calcined at $800{ }^{\circ} \mathrm{C}$ ferrite they were $49.6 \%, 45.5 \%$, and $41.5 \%$. For the $\mathrm{Zn}_{0.5} \mathrm{Co}_{0.5} \mathrm{Fe}_{2} \mathrm{O}_{4}$ ferrite calcined at $250{ }^{\circ} \mathrm{C}$, the mean values of inhibition were obtained, in the incubation times 24,48 , and $72 \mathrm{~h}$, equal to $61.2 \%$, $56.6 \%$, and 52.7\%, respectively. And for the $\mathrm{Zn}_{0.5} \mathrm{Co}_{0.5} \mathrm{Fe}_{2} \mathrm{O}_{4}$ ferrite calcined at $800^{\circ} \mathrm{C}$, the average values of growth inhibition were $58.3 \%, 54.0 \%$, and $51.7 \%$, respectively. From the dispersion control, it was observed that there was no influence on the antibacterial action of the ferrite.

Table 2 presents the values obtained for IC50 for the inhibition analyzes of $S$. aureus strains. Thus, MIC was considered to be greater than $1 \mathrm{mg} / \mathrm{mL}$, with only the IC50 
values expressed in the table. This varied from 0.46 to $1 \mathrm{mg} /$ $\mathrm{mL}$ for the three incubation times tested. The calcination temperature did not induce any significant effect, however, for the ferrites $\mathrm{ZnFe}_{2} \mathrm{O}_{4}$ and $\mathrm{Zn}_{0.5} \mathrm{Co}_{0.5} \mathrm{Fe}_{2} \mathrm{O}_{4}$ calcined at $250{ }^{\circ} \mathrm{C}$, they showed better results. However, amorphous particles probably have superior inhibitory effects when compared to crystalline NP.

Figure 8 expresses the inhibition growth for the ferrites calcined at $250{ }^{\circ} \mathrm{C}\left(800{ }^{\circ} \mathrm{C}\right)$ of $\mathrm{ZnFe}_{2} \mathrm{O}_{4}, \mathrm{CoFe}_{2} \mathrm{O}_{4}$, and $\mathrm{Zn}_{0.5} \mathrm{Co}_{0.5} \mathrm{Fe}_{2} \mathrm{O}_{4}$ in contact with $E$. coli strains $(n=3)$ in the three incubation times evaluated. For the $\mathrm{ZnFe}_{2} \mathrm{O}_{4}$ ferrite calcined at $250{ }^{\circ} \mathrm{C}$, the inhibition averages in the 3 incubation times, were equal to $54.7 \%, 46.4 \%$, and $40.8 \%$, respectively. And the average values obtained for the $\mathrm{ZnFe}_{2} \mathrm{O}_{4}$ ferrite calcined at $800{ }^{\circ} \mathrm{C}$ were equal to $51.0 \%$, $44.6 \%$, and $38.1 \%$, respectively. For the $\mathrm{CoFe}_{2} \mathrm{O}_{4}$ ferrite calcined at $250{ }^{\circ} \mathrm{C}$, in the incubation times of 24,48 , and $72 \mathrm{~h}$, the percentage values of inhibition were equal to $38.5 \%, 31.4 \%$, and $26.8 \%$, respectively. And for the $\mathrm{CoFe}_{2} \mathrm{O}_{4}$ ferrite calcined at $800{ }^{\circ} \mathrm{C}$, the percentage inhibition values were $34.3 \%, 28.4 \%$, and $25.1 \%$. For the $\mathrm{Zn}_{0.5} \mathrm{Co}_{0.5} \mathrm{Fe}_{2} \mathrm{O}_{4}$ ferrite calcined at $250{ }^{\circ} \mathrm{C}$, the mean percentage inhibition values were equal to $48.6 \%, 42.8 \%$, and $38.0 \%$, respectively. And for $\mathrm{Zn}_{0.5} \mathrm{Co}_{0.5} \mathrm{Fe}_{2} \mathrm{O}_{4}$ ferrite, the mean percentage inhibition values were $44.8 \%, 38.2 \%$ and $35.5 \%$, respectively.

Table 3 presents the IC50 values for the analysis of inhibition of $E$. coli strains obtained by non-linear regression. At all incubation times, and both calcination temperatures, MIC values were greater than $1 \mathrm{mg} / \mathrm{mL}$. The IC50 value ranged from 0.91 to $1 \mathrm{mg} / \mathrm{mL}$ for the three incubation times tested and the two calcination temperatures.

A study carried out with $\mathrm{Fe}_{3} \mathrm{O}_{4}$ NPs in contact with the resistant species $E$. coli showed that the antibacterial effect promoted by ferrite in this bacterium is dependent on the concentration. In addition, the authors reported that the size of the ferrite was related to the antibacterial action [41]. A study carried out with zinc oxide, iron oxide, and $\mathrm{Zn} / \mathrm{Fe}$ oxide, showed greater inhibitory action for NPs with a higher molar zinc concentration, obtaining greater inhibition for strains of $S$. aureus than for strains of $E$. coli [20, 42, 43] performed an antibacterial evaluation with $\mathrm{Zn}_{0.5} \mathrm{Co}_{0.5} \mathrm{Fe}_{2} \mathrm{O}_{4}$ ferrite in MRSA ( $S$. aureus Methicillin Resistant) and $E$. coli and were able to confirm greater inhibitory action for $S$. aureus. This inhibition decreased according to the incubation time, in $2 \mathrm{~h}$ there was an approximately $80 \%$ inhibition for $S$. aureus and $70 \%$ for $E$. coli and in 24 it decreased to about $65 \%$ and $50 \%$ inhibition.

The cytotoxicity of NPs on Vero cells was evaluated by MTT assay. Figure 9 shows the viability of Vero cells exposed to $125,250,500$, and $1000 \mu \mathrm{g} / \mathrm{mL}$ of $\mathrm{ZnFe}_{2} \mathrm{O}_{4}$ NPs, $\mathrm{CoFe}_{2} \mathrm{O}_{4}$ NPs, and $\mathrm{Zn}_{0.5} \mathrm{Co}_{0.5} \mathrm{Fe}_{2} \mathrm{O}_{4}$ NPs. The specific values were $\mathrm{IC}_{50}=16.72 \mu \mathrm{g} / \mathrm{mL}$ for $\mathrm{ZnFe}_{2} \mathrm{O}_{4}$ NPs calcined at $250{ }^{\circ} \mathrm{C}, \mathrm{IC}_{50}=16.28 \mu \mathrm{g} / \mathrm{mL}$ for $\mathrm{ZnFe}_{2} \mathrm{O}_{4}$ NPs calcined at $800{ }^{\circ} \mathrm{C}, \mathrm{IC}_{50}=17.65 \mu \mathrm{g} / \mathrm{mL}$ for $\mathrm{CoFe}_{2} \mathrm{O}_{4}$ NPs calcined at $250{ }^{\circ} \mathrm{C}, \mathrm{IC}_{50}=17.73 \mu \mathrm{g} / \mathrm{mL}$ for $\mathrm{CoFe}_{2} \mathrm{O}_{4}$ NPs calcined at $800{ }^{\circ} \mathrm{C}, \mathrm{IC}_{50}=13.42 \mu \mathrm{g} / \mathrm{mL}$ for $\mathrm{Zn}_{0.5} \mathrm{Co}_{0.5} \mathrm{Fe}_{2} \mathrm{O} \mathrm{NPs}$ calcined at $250{ }^{\circ} \mathrm{C}$ and $\mathrm{IC}_{50}=17.24 \mu \mathrm{g} / \mathrm{mL}$ for $\mathrm{Zn}_{0.5} \mathrm{Co}_{0.5} \mathrm{Fe}_{2} \mathrm{O}$ NPs calcined at $800{ }^{\circ} \mathrm{C}$. The value $\mathrm{IC}_{50}=120.5 \mu \mathrm{g} / \mathrm{mL}$ for dispersion vehicle (propylene glycol).

\subsubsection{Agar diffusion test}

Results on the antimicrobial activity of $\mathrm{CoFe}_{2} \mathrm{O}_{4}, \mathrm{ZnFe}_{2} \mathrm{O}_{4}$, and $\mathrm{Zn}_{0.5} \mathrm{Co}_{0.5} \mathrm{Fe}_{2} \mathrm{O}_{4}$ NPs are rare in the literature. In this work, the antimicrobial activities of the synthesized NPs were tested against Gram-positive and Gram-negative bacteria. The antimicrobial effects of the NPs were qualitatively measured by performing agar diffusion test against all the test microorganisms. The results of zones of inhibition are shown in Table 4. The agar plate inhibition tests were performed by the disc diffusion method, as a way to confirm the inhibitory action of the ferrites prepared here. The disk inhibition tests, following the Kirby-Bauer method [44]. The absence of microbial growth around the NPs is an indirect measure of the ability of the NP to inhibit the growth. With a concentration of $2 \mathrm{mg} / \mathrm{mL}$, was evident the formation of growth inhibition halos around the disks on the medium with the bacterium. After the dispersion using the nanoemulsion was possible to obtain clearer and evident inhibition halos for all synthesized ferrites, as shown in Fig. 10.

Figure 10 shows a visual difference between the formed diameters by the inhibition halos created by zinc, cobalt ferrites, and $\mathrm{Co}^{2+}$ substituted zinc ferrite calcined at $250{ }^{\circ} \mathrm{C}$ and $800^{\circ} \mathrm{C}$ in contact with $S$. aureus strains. It was observed that the calcination temperature changed the diameter of the formed halo.

Figure $10 \mathrm{a}$, b shows the halos formed for $\mathrm{ZnFe}_{2} \mathrm{O}_{4} \mathrm{NPs}$ calcined at 250 and $800^{\circ} \mathrm{C}$ when in contact with $S$. aureus strains. The diameter measurement of the formed halo for $\mathrm{ZnFe}_{2} \mathrm{O}_{4} \mathrm{NPs}$ calcined at 250 and $800{ }^{\circ} \mathrm{C}$ were 13.1 and $12.1 \mathrm{~mm}$, as shown in Table 4 .

Figure 10c, d shows the halos formed for $\mathrm{CoFe}_{2} \mathrm{O}_{4} \mathrm{NPs}$ calcined at 250 and $800{ }^{\circ} \mathrm{C}$ when in contact with $S$. aureus strains. The diameter measurement of the formed halo for $\mathrm{CoFe}_{2} \mathrm{O}_{4}$ NPs calcined at 250 and $800{ }^{\circ} \mathrm{C}$ was $9.4 \mathrm{~mm}$ and $8.7 \mathrm{~mm}$, as shown in Table 4 .

The last NP placed in contact with $S$. aureus strains in the Agar diffusion test was the $\mathrm{Zn}_{0.5} \mathrm{Co}_{0.5} \mathrm{Fe}_{2} \mathrm{O}_{4}$, as shown in Fig. 10e, f. In this case, the diameter of the halo formed did not change significantly. The diameter measurement of the formed halo for $\mathrm{Zn}_{0.5} \mathrm{Co}_{0.5} \mathrm{Fe}_{2} \mathrm{O}_{4} \mathrm{NPs}$ calcined at 250 and $800{ }^{\circ} \mathrm{C}$ were $10.9 \mathrm{~mm}$ and $10.5 \mathrm{~mm}$, as shown in Table 4 . In general, the diameters of the halos formed for $\mathrm{ZnFe}_{2} \mathrm{O}_{4} \mathrm{NPs}$ 
Fig. 5 TEM images for

$\mathrm{ZnFe}_{2} \mathrm{O}_{4}, \mathrm{CoFe}_{2} \mathrm{O}_{4}$, and

$\mathrm{Zn}_{0.5} \mathrm{Co}_{0.5} \mathrm{Fe}_{2} \mathrm{O}_{4}$ NPs after

calcination at 250 and $800^{\circ} \mathrm{C}$.

$\mathrm{ZnFe}_{2} \mathrm{O}_{4} \mathrm{NPs}$ after calcination at a, b $250{ }^{\circ} \mathrm{C}$ and $800^{\circ} \mathrm{C}$ c, d.

$\mathrm{CoFe}_{2} \mathrm{O}_{4} \mathrm{NPs}$ after calcination at

$250{ }^{\circ} \mathrm{C}(\mathbf{e}, \mathbf{f})$ and $800^{\circ} \mathrm{C}(\mathbf{g}, \mathbf{h})$, and $\mathrm{Zn}_{0.5} \mathrm{Co}_{0.5} \mathrm{Fe}_{2} \mathrm{O}_{4}$ NPs after calcination at $(\mathbf{i}, \mathbf{j}) 250{ }^{\circ} \mathrm{C}$ and $800{ }^{\circ} \mathrm{C}(\mathbf{k}, \mathbf{l})$
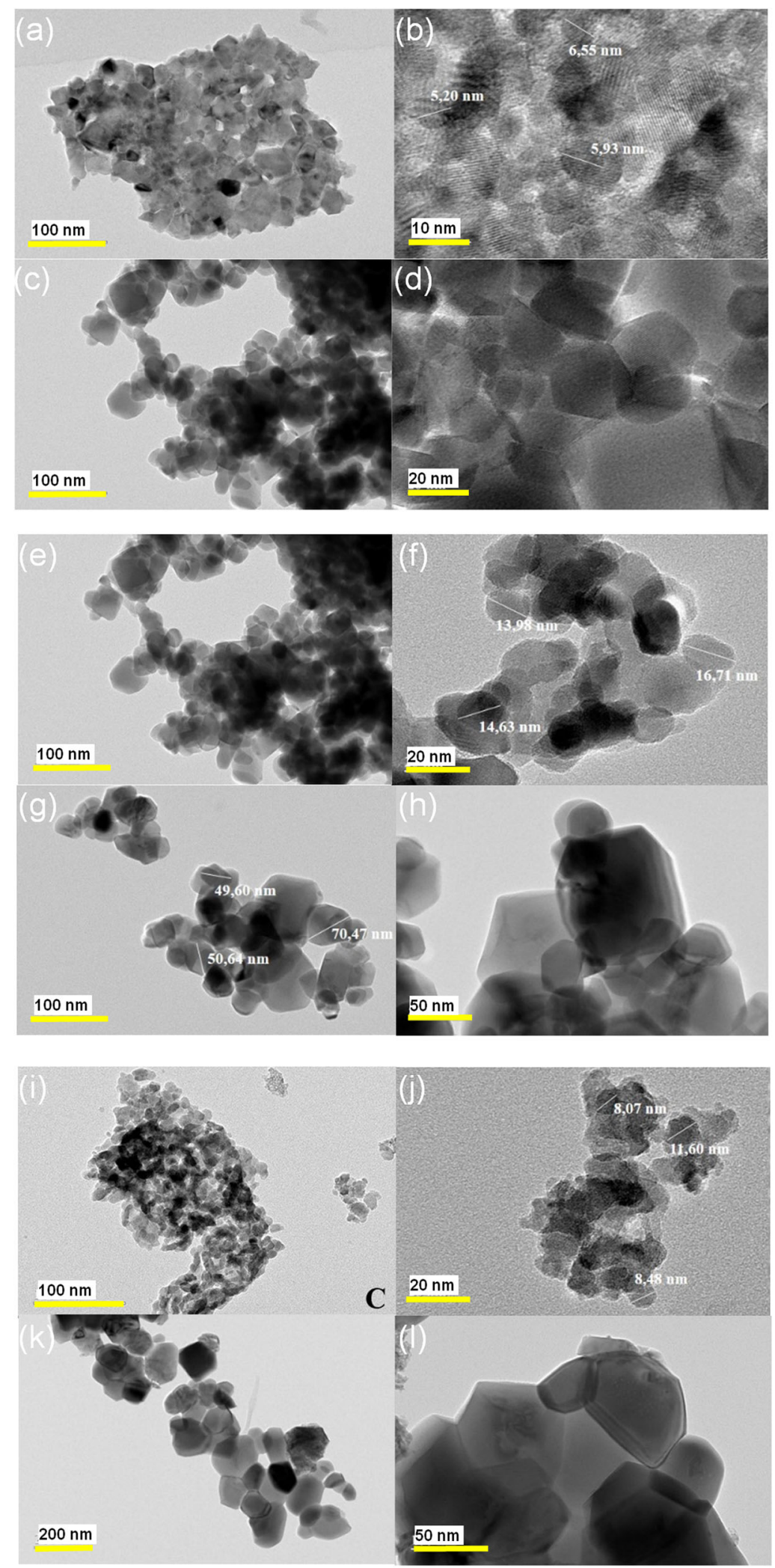

were slightly larger for NPs calcined at low temperature. These measured results suggest that the crystalline structure of NPs calcined at low temperature was slightly more effective in inhibiting $S$. aureus. XRD data shows that at low temperature, calcined NPs have more characteristics of amorphous material. 

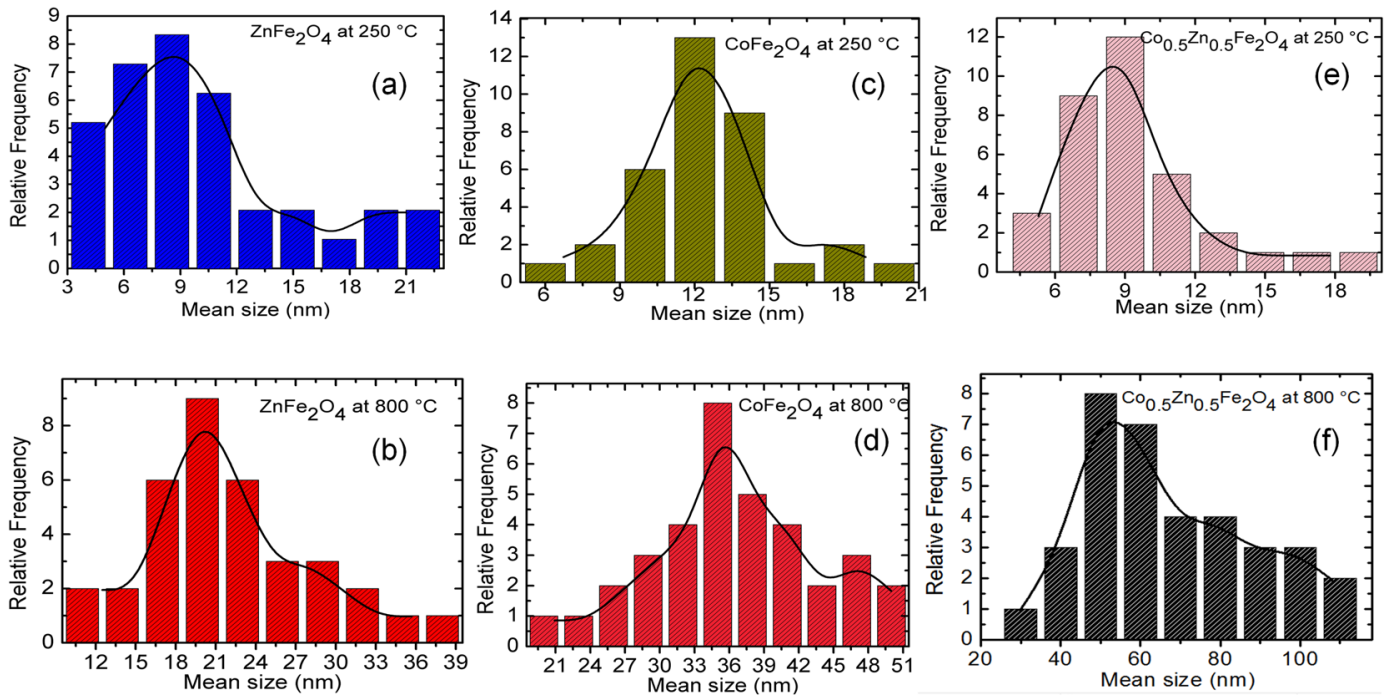

Fig. 6 Histogram for $\mathrm{ZnFe}_{2} \mathrm{O}_{4}, \mathrm{CoFe}_{2} \mathrm{O}_{4}$, and $\mathrm{Zn}_{0.5} \mathrm{Co}_{0.5} \mathrm{Fe}_{2} \mathrm{O}_{4} \mathrm{NPs}$ after calcination at 250 and $800{ }^{\circ} \mathrm{C}$. $\mathrm{ZnFe}_{2} \mathrm{O}_{4} \mathrm{NPs}$ after calcination at a $250{ }^{\circ} \mathrm{C}$ and $800{ }^{\circ} \mathrm{C}$ (b). $\mathrm{CoFe}_{2} \mathrm{O}_{4} \mathrm{NPs}$ after calcination at c $250{ }^{\circ} \mathrm{C}$ and $800^{\circ}(\mathbf{d})$, and $\mathrm{Zn}_{0.5} \mathrm{Co}_{0.5} \mathrm{Fe}_{2} \mathrm{O}_{4} \mathrm{NPs}$ after calcination at (e) $250{ }^{\circ} \mathrm{C}$ and $800{ }^{\circ} \mathrm{C}(\mathbf{f})$

Fig. 7 Percentage of growth inhibition of $S$. aureus strains $(n=3)$ presented by the tested concentrations of zinc, cobalt, and mixed ferrites dispersed by nanoemulsion, after incubation for 24,48 , and $72 \mathrm{~h}$ at $37^{\circ} \mathrm{C}$

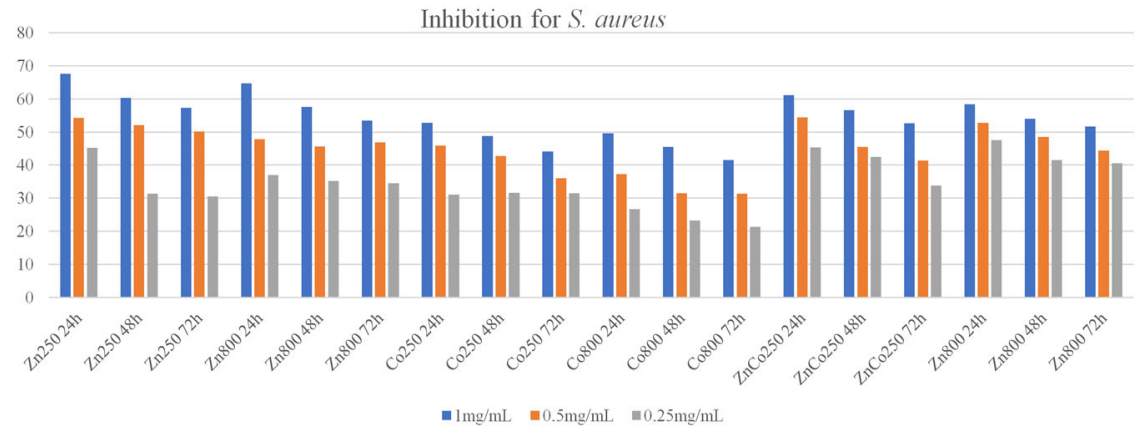

Inhibition for $E$. coli

Fig. 8 Percentage of growth inhibition of $E$. coli strains $(n=3)$ presented by the tested concentrations of zinc, cobalt, and mixed ferrites dispersed by nanoemulsion, after incubation for 24,48 , and $72 \mathrm{~h}$ at $37^{\circ} \mathrm{C}$

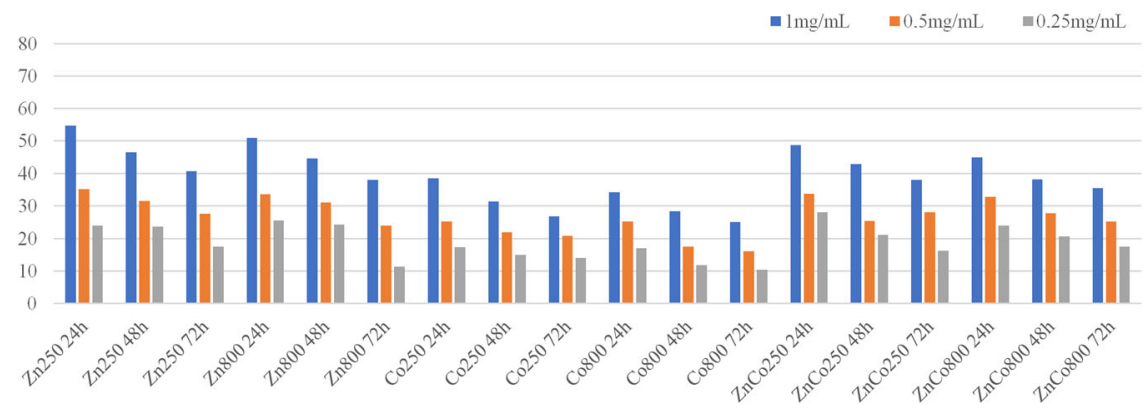

The second step was to place the same NPs in the agar diffusion test in contact with $E$. coli strains. The procedure used was the same as for $S$. aureus strain.

Figure 11a, b shows the halos formed for $\mathrm{ZnFe}_{2} \mathrm{O}_{4}$ NPs calcined at 250 and $800{ }^{\circ} \mathrm{C}$ when in contact with $E$. coli strains. The diameter measurement of the formed halo for $\mathrm{ZnFe}_{2} \mathrm{O}_{4} \mathrm{NPs}$ calcined at 250 and $800{ }^{\circ} \mathrm{C}$ was $8.8 \mathrm{~mm}$ and $7.8 \mathrm{~mm}$, as shown in Table 4.
Figure 11c, d shows the halos formed for $\mathrm{CoFe}_{2} \mathrm{O}_{4} \mathrm{NPs}$ calcined at 250 and $800{ }^{\circ} \mathrm{C}$ when in contact with E. coli strains. The diameter measurement of the formed halo for $\mathrm{CoFe}_{2} \mathrm{O}_{4} \mathrm{NPs}$ calcined at $250{ }^{\circ} \mathrm{C}$ and $800{ }^{\circ} \mathrm{C}$ were $6.9 \mathrm{~mm}$ and 6.0, as shown in Table 4.

The last NP placed in contact with $E$. coli strains in the Agar diffusion test was the $\mathrm{Zn}_{0.5} \mathrm{Co}_{0.5} \mathrm{Fe}_{2} \mathrm{O}_{4}$, as shown in Fig. 11e, f. The diameter measurement of the formed halo 
Table 2 Table referring to the IC50 values found for tests with ferrites in contact with $S$. aureus strains at different incubation times. $n=3$

\begin{tabular}{llll}
\hline IC50 obtained for strains of $S$. aureus \\
\hline Ferrite & \multicolumn{4}{l}{ Incubation time } \\
\cline { 2 - 4 } & $24 \mathrm{~h}$ & $48 \mathrm{~h}$ & $72 \mathrm{~h}$ \\
\hline $\mathrm{ZnFe}_{2} \mathrm{O}_{4}$ at $250^{\circ} \mathrm{C}$ & 460.7 & 480.1 & 464.7 \\
$\mathrm{ZnFe}_{2} \mathrm{O}_{4}$ at $800^{\circ} \mathrm{C}$ & 522.4 & 547.6 & 521.2 \\
$\mathrm{CoFe}_{2} \mathrm{O}_{4}$ at $250^{\circ} \mathrm{C}$ & 948.4 & $>1000$ & $>1000$ \\
$\mathrm{CoFe}_{2} \mathrm{O}_{4}$ at $800^{\circ} \mathrm{C}$ & $>1000$ & $>1000$ & $>1000$ \\
$\mathrm{Zn}_{0.5} \mathrm{Co}_{0.5} \mathrm{Fe}_{2} \mathrm{O}_{4}$ at $250^{\circ} \mathrm{C}$ & 465.0 & 549.6 & 949.1 \\
$\mathrm{Zn}_{0.5} \mathrm{Co}_{0.5} \mathrm{Fe}_{2} \mathrm{O}_{4}$ at $800^{\circ} \mathrm{C}$ & 473.6 & 515.9 & 966.9 \\
\hline
\end{tabular}

Table 3 Table referring to the IC50 values found for tests with ferrites in contact with $\mathrm{E}$. coli strains. $n=3$

\begin{tabular}{llll}
\hline IC50 obtained for strains of $E$. coli & & \\
\hline Ferrite & \multicolumn{4}{l}{ Incubation time } \\
\cline { 2 - 4 } & $24 \mathrm{~h}$ & $48 \mathrm{~h}$ & $72 \mathrm{~h}$ \\
\hline $\mathrm{ZnFe}_{2} \mathrm{O}_{4}$ at $250^{\circ} \mathrm{C}$ & 913.8 & $>1000$ & $>1000$ \\
$\mathrm{ZnFe}_{2} \mathrm{O}_{4}$ at $800^{\circ} \mathrm{C}$ & 980.2 & $>1000$ & $>1000$ \\
$\mathrm{CoFe}_{2} \mathrm{O}_{4}$ at $250^{\circ} \mathrm{C}$ & $>1000$ & $>1000$ & $>1000$ \\
$\mathrm{CoFe}_{2} \mathrm{O}_{4}$ at $800^{\circ} \mathrm{C}$ & $>1000$ & $>1000$ & $>1000$ \\
$\mathrm{Zn}_{0.5} \mathrm{Co}_{0.5} \mathrm{Fe}_{2} \mathrm{O}_{4}$ at $250^{\circ} \mathrm{C}$ & $>1000$ & $>1000$ & $>1000$ \\
$\mathrm{Zn}_{0.5} \mathrm{Co}_{0.5} \mathrm{Fe}_{2} \mathrm{O}_{4}$ at $800^{\circ} \mathrm{C}$ & $>1000$ & $>1000$ & $>1000$ \\
\hline
\end{tabular}

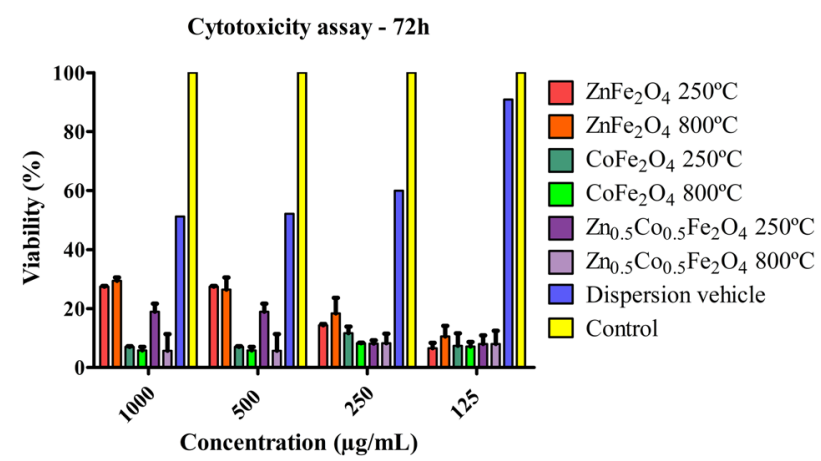

Fig. 9 Vero cells were incubated with various concentrations of $\mathrm{ZnFe}_{2} \mathrm{O}_{4}, \mathrm{CoFe}_{2} \mathrm{O}_{4}$, and $\mathrm{Zn}_{0.5} \mathrm{Co}_{0.5} \mathrm{Fe}_{2} \mathrm{O}_{4} \mathrm{NPs}(125-1000 \mu \mathrm{g} / \mathrm{mL})$ for $72 \mathrm{~h}$ and viability cell was measured using MTT assay. The results are expressed as the mean + standard derivation of triplicate experiment. Differences between the dispersion component and nanoparticles were measured using ANOVA test. The results showed statistical significance between the NPs and the dispersion component $(p<0.005)$

for $\mathrm{Zn}_{0.5} \mathrm{Co}_{0.5} \mathrm{Fe}_{2} \mathrm{O}_{4} \mathrm{NPs}$ calcined at 250 and $800{ }^{\circ} \mathrm{C}$ was $7.7 \mathrm{~mm}$ and $7.0 \mathrm{~mm}$, as shown in Table 4 . Similarly, the diameters of the halos formed for $\mathrm{ZnFe}_{2} \mathrm{O}_{4}$ NPs were slightly larger for NPs calcined at low temperature. These measured results suggest that the crystalline structure of NPs calcined at low temperature was slightly more effective in inhibiting $E$. coli strains.
Table 4 Averages of the diameters of the inhibition halos of each ferrite tested in strains of $S$. aureus $(n=3)$ and E. coli $(n=3)$

\begin{tabular}{lll}
\hline Ferrite & \multicolumn{2}{l}{$\begin{array}{l}\text { Average halo diameters (mm) } \\
\text { for each species }\end{array}$} \\
\cline { 2 - 3 } & S. aureus & E. coli \\
\hline $\mathrm{ZnFe}_{2} \mathrm{O}_{4}$ at $250^{\circ} \mathrm{C}$ & 13.1 & 8.8 \\
$\mathrm{ZnFe}_{2} \mathrm{O}_{4}$ at $800^{\circ} \mathrm{C}$ & 12.1 & 7.8 \\
$\mathrm{CoFe}_{2} \mathrm{O}_{4}$ at $250{ }^{\circ} \mathrm{C}$ & 9.4 & 6.9 \\
$\mathrm{CoFe}_{2} \mathrm{O}_{4}$ at $800{ }^{\circ} \mathrm{C}$ & 8.7 & 6.0 \\
$\mathrm{Zn}_{0.5} \mathrm{Co}_{0.5} \mathrm{Fe}_{2} \mathrm{O}_{4}$ at $250{ }^{\circ} \mathrm{C}$ & 10.9 & 7.7 \\
$\mathrm{Zn}_{0.5} \mathrm{Co}_{0.5} \mathrm{Fe}_{2} \mathrm{O}_{4}$ at $800{ }^{\circ} \mathrm{C}$ & 10.5 & 7.0 \\
$\mathrm{Chloramphenicol}$ & 24 & 20 \\
Negative control & 0 & 0 \\
Dispersion control & 0.9 & 0.6 \\
\hline
\end{tabular}

The validity of the agar diffusion method was verified using the classic antibiotic chlorophenicolc. It is used as a controls. Figure 12 shows the inhibition halos for bacteria $S$. aureus in contact with chloramphenicol antibiotic controls (A), negative control (distilled water in the disc) (B), and control of the dispersion used in the test (nanoemulsion deposited in the disc) (C). Was also compared the antibiotic chloramphenicol effect (D), negative control (E), and the nanoemulsion (F) in contact with the E. coli bacteria.

The results presented in the figures show that the nanoemulsion did not interfere significantly in the results of inhibition of the produced NPs, when tested with $E$. coli and $S$. aureus, as shown in Table 4. A study carried out with $\alpha$ $\mathrm{Fe}_{2} \mathrm{O}_{3}$ (hematite) also showed that $S$. aureus bacteria are more sensitive than $E$. coli in an agar diffusion test, which is due to the greater resistance of Gram-negative because it has an extra lipid membrane, which makes it difficult the passage of NPs [45]. The authors Mandal et al. [46], showed that the inhibition halos formed by zinc ferrites are larger for $S$. aureus than when testing with $E$. coli. In this study, an inhibition zone equal to $22 \mathrm{~mm}$ was obtained for $S$. aureus and $14.6 \mathrm{~mm}$ for E. coli. In general, our results for the sizes of inhibition halos are of the same order of magnitude as those obtained by Mandal et al. Another study whose results were similar to ours is with NPs of $\mathrm{Mn}_{1}$ ${ }_{-x} \mathrm{Ni}_{x} \mathrm{Fe}_{2} \mathrm{O}_{4}$, the authors obtained, using the agar well diffusion method, halos equal to $(18 \mathrm{~mm})$ for $S$. aureus and smaller halos $(12 \mathrm{~mm})$ for $E$. coli [16]. Tests using the modified Kirby-Bauer diffusion method showed that for greater zinc molarities in the mixed cobalt and zinc ferrite, greater inhibition halos were formed [24]. Similar to this study, it was also observed in the present study that the halos formed for the cobalt ferrites were inferior to the halos formed for the other ferrites. Ashour et al. [47], in tests with $\mathrm{Zn}_{0.5} \mathrm{Co}_{0.5} \mathrm{Fe}_{2} \mathrm{O}_{4}$ by disk diffusion, showed that strains of $S$. aureus compared to strains of $E$. coli showed a greater 

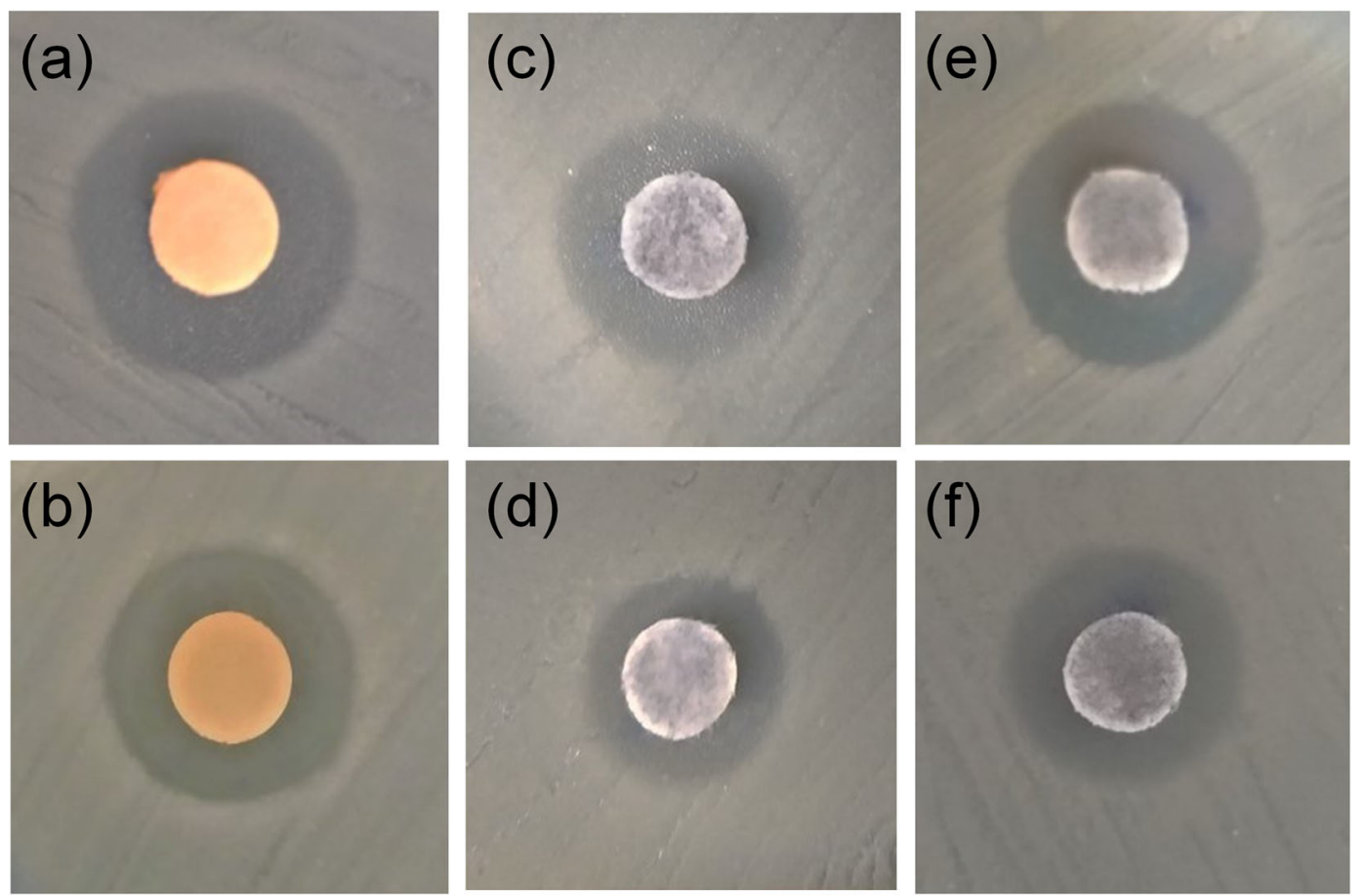

Fig. 10 Disc diffusion test for $S$. aureus strains $(n=3)$ and inhibition halos formed by ferrites dispersed by nanoemulsion. $\mathrm{ZnFe}_{2} \mathrm{O}_{4}$ calcined at $250{ }^{\circ} \mathrm{C}(\mathbf{a})$, and $800{ }^{\circ} \mathrm{C}(\mathbf{b}) . \mathrm{CoFe}_{2} \mathrm{O}_{4}$ calcined at $250{ }^{\circ} \mathrm{C}(\mathbf{c})$, and $800{ }^{\circ} \mathrm{C}(\mathbf{d}) . \mathrm{Zn}_{0.5} \mathrm{Co}_{0.5} \mathrm{Fe}_{2} \mathrm{O}_{4}$ calcined at $250{ }^{\circ} \mathrm{C}(\mathbf{e})$, and $800{ }^{\circ} \mathrm{C}(\mathbf{f})$
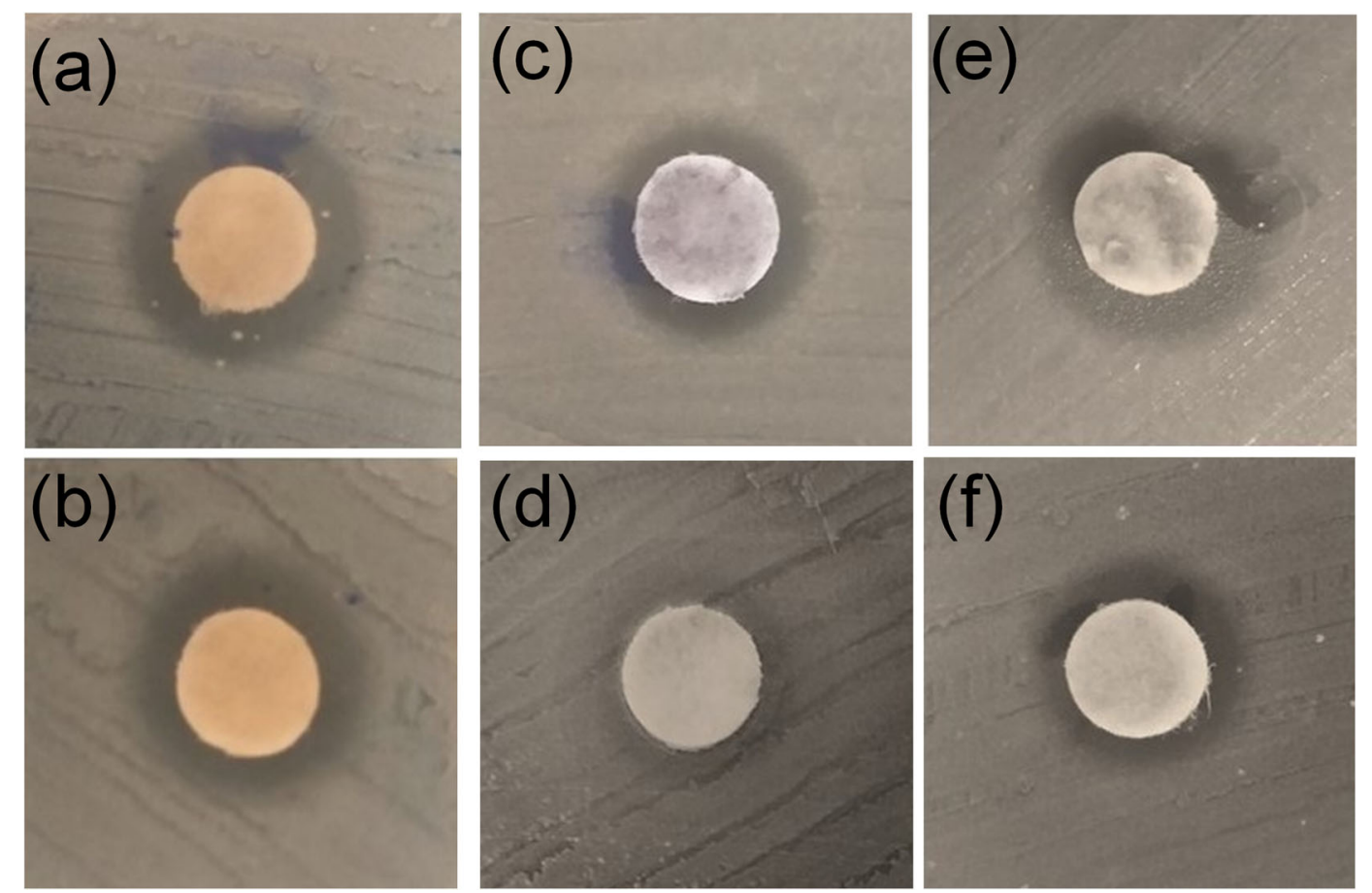

Fig. 11 Disc diffusion test for $E$. coli strains $(n=3)$ and inhibition halos formed by ferrites dispersed by nanoemulsion. $\mathrm{ZnFe}_{2} \mathrm{O}_{4}$ calcined at $250{ }^{\circ} \mathrm{C}(\mathbf{a})$, and $800{ }^{\circ} \mathrm{C}(\mathbf{b}) . \mathrm{CoFe}_{2} \mathrm{O}_{4}$ calcined at $250{ }^{\circ} \mathrm{C}(\mathbf{c})$, and $800{ }^{\circ} \mathrm{C}(\mathbf{d}) . \mathrm{Zn}_{0.5} \mathrm{Co}_{0.5} \mathrm{Fe}_{2} \mathrm{O}_{4}$ calcined at $250{ }^{\circ} \mathrm{C}(\mathbf{e})$, and $800{ }^{\circ} \mathrm{C}(\mathbf{f})$

inhibition halo, which was $16 \mathrm{~mm}$ for positive-Gram and $11 \mathrm{~mm}$ for negative-Gram. Ashour et al. [47], which tested $S$. aureus, in contact with mixed zinc and cobalt ferrite
$\left(\mathrm{Zn}_{0.75} \mathrm{Co}_{0.25} \mathrm{Fe}_{2} \mathrm{O}_{4}\right)$, in which a high inhibitory power was demonstrated, with the formation of $15 \mathrm{~mm}$ inhibition halos. Sharma et al. [48], using cobalt ferrite to combat S. aureus, 


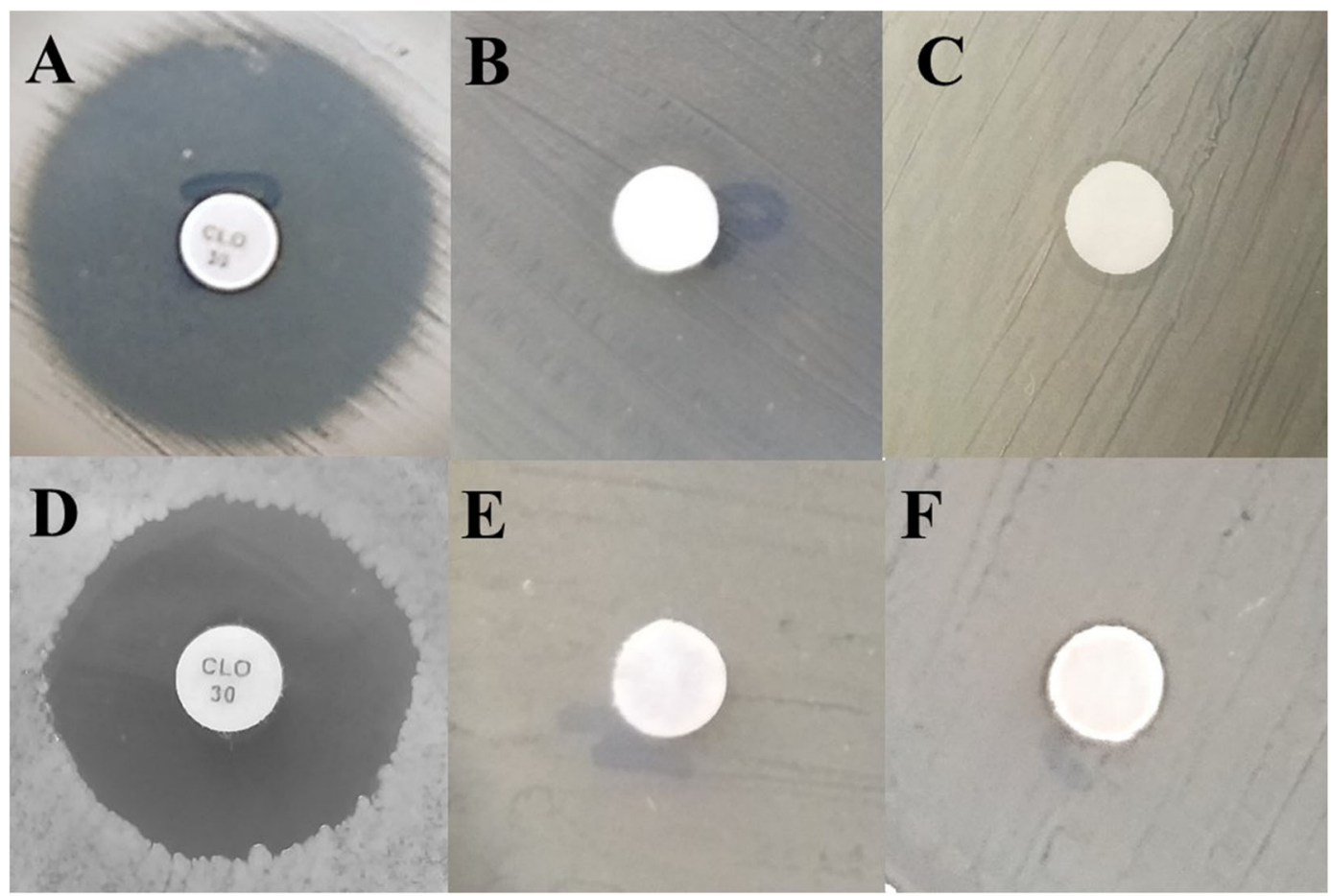

Fig. 12 Disc diffusion test for strains of $S$. aureus (A-C) and E. coli (D-F), $n=3$, and inhibition halos formed by the controls. A, D Chloramphenicol; $\mathbf{B}, \mathbf{E}$ negative control (distilled water); and (C, F) dispersion control (nanoemulsion)

E. coli, and other strains, showed that the tested ferrite showed inhibition potential for both classes of bacteria, as both are negatively charged, which favor interaction electrostatic between the cell and the NPs or ions released from them.

Some factors, such as the composition and structure of the cell wall, may also be related to the rate of bacterial death. It is seen that the inhibitory capacity for $S$. aureus and $E$. coli bacteria are different. However, the structure of the bacteria can promote greater attraction to NPs, since $E$. coli consists of lipid A, lipopolysaccharide, and peptidoglycan; while the cell wall of $S$. aureus is composed mostly of peptidoglycan [23, 49-51]. Some studies suggest that the inhibitory action generated by NPs is due to the generation of reactive oxygen species (ROS), which end up causing bacterial death. Results by Arakha et al. [52] showed that the antimicrobial mechanism involved in bacterial death is through the release of ROS when in contact with iron oxide NPs, in which NPs with positive and negative surface charges were tested, obtaining greater antimicrobial activity to those positively charged. The mechanism generated by photocatalytic reactions causes oxidative stress in bacteria. These end up suffering a rupture of the cell membrane with the leakage of cytoplasmic materials [53]. Other possible mechanisms are the attraction of NPs to the bacterial surface, due to the differences in loads. Metal cations are attracted by the negative surface charge of bacteria, they accumulate allowing entry into the cell, causing pores in the wall/membrane and loss of intracellular content [54].

\section{Conclusions}

The synthesis of $\mathrm{ZnFe}_{2} \mathrm{O}_{4}, \mathrm{CoFe}_{2} \mathrm{O}_{4}$, and $\mathrm{Zn}_{0.5} \mathrm{Co}_{0.5} \mathrm{Fe}_{2} \mathrm{O}_{4}$ ferrites was successful by the sol-gel method. FTIR measurements showed important peaks for the transition metal ferrites of $\mathrm{Zn}$ and Co. The analysis by XRF detected higher percentages of iron with proportions of $2: 1$ for both Fe:Zn and Fe:Co. X-ray diffraction made it possible to structurally characterize ferrites, confirming that the material is of the crystalline type and that the degree of crystallinity has increased for higher calcination temperatures $\left(800^{\circ} \mathrm{C}\right)$. The micrographs obtained by transmission electron microscopy showed that the ferrites calcined at a lower temperature, $250{ }^{\circ} \mathrm{C}$ were small in size compared to the ferrites calcined at a higher temperature, $800^{\circ} \mathrm{C}$. The antibacterial activity of the three ferrites was partially shown for the tests at concentrations of $1 \mathrm{mg} / \mathrm{mL}, 0.5 \mathrm{mg} / \mathrm{mL}$, and $0.25 \mathrm{mg} / \mathrm{mL}$ with MIC greater than $1000 \mu \mathrm{g} / \mathrm{mL}$ for the two bacteria tested. According to the halos obtained, for discs at a concentration of $2 \mathrm{mg} / \mathrm{mL}$, it was concluded that there was greater inhibition efficiency in the order of $\mathrm{ZnFe}_{2} \mathrm{O}_{4}>\mathrm{Zn}_{0.5} \mathrm{Co}_{0.5} \mathrm{Fe}_{2} \mathrm{O}_{4}$ $>\mathrm{CoFe}_{2} \mathrm{O}_{4}$. Thus, it is concluded that the synthesized ferrites have dose-inhibitory capacity dependence. 
Acknowledgements The following are thanked for technical assistance: Tatiane Oliveira dos Santos of the Labmic at Universidade Federal de Goiás for Transmission Electron Microscopy analysis. This work was supported by Shanghai Natural Science Foundation (20ZR1401700), and the National Natural Science Foundation of China (21703031). The authors would like to thanks Thiago Oliveira Lima (Universidade Federal de Jataí) for technical assistance.

Author contributions DOM, GSS, and MVBS devised the concept, with assistance from $\mathrm{AB}$ for antibacterial testing. NPs were prepared by MVBS, JW, and AP. Infrared spectroscopy, X-ray diffraction, transmission electron microscopy were conducted by DOM, AP, and MVBS. Antibacterial testing was performed by MVS, MLM, and VGdC. The manuscript was jointly drafted by AP and JW All authors gave final approval for publication.

Funding This work was supported by Shanghai Natural Science Foundation (20ZR1401700), CAPES under Master Fellowship, FAPEG Project 07/2016 (23187), CNPq Grant (310774/2020-9) and National Natural Science Foundation of China (21703031).

\section{Compliance with ethical standards}

Conflict of interest The authors declare no competing interests.

Publisher's note Springer Nature remains neutral with regard to jurisdictional claims in published maps and institutional affiliations.

Open Access This article is licensed under a Creative Commons Attribution 4.0 International License, which permits use, sharing, adaptation, distribution and reproduction in any medium or format, as long as you give appropriate credit to the original author(s) and the source, provide a link to the Creative Commons license, and indicate if changes were made. The images or other third party material in this article are included in the article's Creative Commons license, unless indicated otherwise in a credit line to the material. If material is not included in the article's Creative Commons license and your intended use is not permitted by statutory regulation or exceeds the permitted use, you will need to obtain permission directly from the copyright holder. To view a copy of this license, visit http://creativecommons. org/licenses/by/4.0/.

\section{References}

1. Boisseau P, Loubaton B. Nanomedicine, nanotechnology in medicine. Comptes Rendus Phys. 2011;12:620-36.

2. Singh R. Nanotechnology based therapeutic application in cancer diagnosis and therapy. Biotech. 2019;9:415.

3. Lekshmi PNCJ. Antibacterial activity of nanoparticles from Allium sp. J Microbiol Biotechnol Res. 2012;2:115-19.

4. Chen G, Qiu H, Prasad PN, Chen X. Upconversion nanoparticles: design, nanochemistry, and applications in theranostics. Chem Rev. 2014;114:5161-214.

5. Gharibshahian M, Nourbakhsh MS, Mirzaee O. Evaluation of the superparamagnetic and biological properties of microwave assisted synthesized $\mathrm{Zn} \& \mathrm{Cd}$ doped $\mathrm{CoFe} 2 \mathrm{O} 4$ nanoparticles via Pechini sol-gel method. J Sol-Gel Sci Technol. 2018;85:684-92.

6. Schettino MA Jr, Cunha AG, Nunes E, Passamani EC, Freitas JCC, Emmerich FG, et al. Synthesis and characterization of nanostructured iron compounds prepared from the decomposition of iron pentacarbonyl dispersed into carbon materials with varying porosities. J Nanopart Res. 2016;18:90.
7. Cotica LF, Freitas VF, Silva DM, Honjoya K, Honjoya K, Santos IA, et al. Thermal decomposition synthesis and assessment of effects on blood cells and in vivo damages of cobalt ferrite nanoparticles. J Nano Res. 2014;28:131-40.

8. Cullity BD, Graham CD. Introduction to magnetic materials. 2nd ed. New Jersey: IEEE Press Editorial; 2009. 550.

9. Muccillo R, Carmo JR. Synthesis and characterization of strontium and calcium titanate polycrystalline powders by a modified polymeric precursor technique. Mater Sci Forum. 2012;727:904-8.

10. Danks AE, Hall SR, Schnepp Z. The evolution of sol-gel chemistry as o techique for materials synthesis. Mater Horiz. 2016;3:91-112.

11. Nunes EDS, Viali WR, Silva SW, da, Coaquira JAH, Garg VK, Oliveira AC, et al. Characterization of tetraethylene glycol passivated iron nanoparticles. Appl Surf Sci. 2014;315:337-45.

12. Maul J, Brito AS, de Oliveira ALM, Lima SJG, Maurera MAMA, Keyson D, et al. Influence of the synthesis media in the properties of $\mathrm{CuO}$ obtained by microwave-assisted hydrothermal method. J Therm Anal Calorim. 2011;106:519-23.

13. Roca I, Akova M, Baquero F, Carlet J, Cavaleri M, Coenen S, et al. The global threat of antimicrobial resistance: science for intervention. New Microbes New Infect. 2015;6:22-9.

14. Santos AF, Brotto DF, Favarin LRV, Cabeza NA, Andrade GR, Batistote M, et al. Study of the antimicrobial activity of metal complexes and their ligands through bioassays applied to plant extracts. Braz J Pharmacogn. 2014;24:309-15.

15. Ouay BL, Stellacci F. Antibacterial activity of silver nanoparticles: a surface science insight. Nano Today. 2015;10:339-54.

16. Jesudoss SK, Vijaya JJ, Kennedy LJ, Iyyappa Rajan P, AlLohedan HA, Ramalingam RJ, et al. Studies on the eficiente dual performance of $\mathrm{Mn}_{1-\mathrm{x}} \mathrm{Ni}_{\mathrm{x}} \mathrm{Fe}_{2} \mathrm{O}_{4}$ spinel nanoparticles in photodegradation and antibacterial activity. J Photochem. Photobiol B Biol. 2016;165:121-32.

17. Lima DR, Jiang N, Liu X, Wang J, Vulcani VAS, Martins A, et al. Employing calcination as a facile strategy to reduce the cytotoxicity in $\mathrm{CoFe}_{2} \mathrm{O}_{4}$ and $\mathrm{NiFe}_{2} \mathrm{O}_{4}$ nanoparticles. ACS Appl Mater Interfaces. 2017;9:39830-38.

18. Hussain SM, Warheit DB, Ng SP, Comfort KK, Grabinski CM, Braydich-Stolle LK. At the crossroads of nanotoxicology in vitro: past achievements and current challenges. Toxicol Sci. 2015;147:5-16.

19. Vila L, Rubio L, Annangi B, García-Rodríguez A, Marcos R, Hernández A. Frozen dispersions of nanomaterials are a useful operational procedure in nanotoxicology. Nanotoxicology. 2017;11:31-40.

20. Iqbal S, Fakhar-e-Alam M, Atif M, Amin N, Alimgeer KS, Aqrabul-Ahmad AA, et al. Structural, morphological, antimicrobial, and in vitro photodynamic therapeutic assessments of novel $\mathrm{Zn}^{+2}$ substituted cobalto ferrite nanoparticles. Phys Res. 2019;15:102529.

21. CLSI. M100 - S23 Performance standards for antimicrobial susceptibility testing; TwentyThird Informational Supplement, Clinical and Laboratory Standards Institute; 2013, Wayne, USA.

22. Fakae LB, Stevenson CW, Zhu X-Q, Elsheikha HM. In vitro activity of Camellia sinensis (green tea) against trophozoites and cysts of Acanthamoeba castellanii. Int J Parasitol Drugs Drug Resist. 2020;13:59-72.

23. Sanpo N, Berndt CC, Wen C, Wang J. Transition metalsubstituted cobalto ferrite nanoparticles for biomedical applications. Acta Biomater. 2013;9:5830-37.

24. Sanpo N, Berndt CC, Wang J. Microstructural and antibacterial properties of zinc-substituted cobalt ferrite nanopowders synthesized by sol-gel methods. J Appl Phys. 2012;112:084333. 
25. Sanpo N, Wang J, Berndt CC. Sol-gel synthesized coppersubstituted cobalt ferrite nanoparticles for biomedical applications. J Nano Res. 2013;22:95-106.

26. Suppuraj P, Thirunarayanan G, Swaminathan M, Muthuvel I. Facile synthesis of spinel nanocrystalline $\mathrm{ZnFe}_{2} \mathrm{O}_{4}$ : enhanced photocatalytic and microbial applications. Mater Sci Appl Chem. 2017;34:5-11.

27. Vinosha PA, Mary GIN, Mahalakshmi K, Mely LA, Jerome DS. Study on cobalt ferrite nanoparticles synthesized by coprecipitation technique for photo-fenton application. Mechan Mater Sci Eng. 2017;9. https://doi.org/10.2412/mmse.36.49.466.

28. Naseri MG, Saion B, Kamali AN. Overview on nanocrystalline $\mathrm{ZnFe}_{2} \mathrm{O}_{4}, \mathrm{MnFe}_{2} \mathrm{O}_{4}$ and $\mathrm{CoFe}_{2} \mathrm{O}_{4}$ synthesized by a thermal treatment method. Int Sch Res Netw Nanotecnol. 2012;2012:11.

29. Sundararajan M, Kennedy LJ, Vijaya JJ, Aruldoss U. Microwave combustion synthesis of $\mathrm{Co}_{1-\mathrm{x}} \mathrm{Zn}_{\mathrm{x}} \mathrm{Fe}_{2} \mathrm{O}_{4}(0<=\mathrm{x}<=0.5)$ : structural, magnetic, optical and vibrational spectroscopic studies, Spectrochimica. Spectrochim Acta A Mol Biomol Spectrosc. 2015;150:421-30.

30. Sundararajan M, Kennedy LJ, Vijaya JJ. Synthesis and characterization of cobalt substituted zinc ferrite nanoparticles by microwave combustion method. J Nanosci Nanotechnol. 2015;15:6719-28.

31. Lemdek EM, Benkhouja K, Jaafari K, Bettach M, Tahiri M, Masaif N, et al. Structural and magnetic properties of nanometric $\mathrm{Zn}_{0.5} \mathrm{Co}_{0.5} \mathrm{Fe}_{2} \mathrm{O}_{4}$ prepared by hydrothermal method. Mol Cryst Liq Cryst. 2016;627:125-32.

32. Lemine OM, Bououdina M, Sajieddine M, Al-Saie AM, Shafi M, Khatan A, et al. Synthesis, structural, magnetic and optical properties of nanocrystalline $\mathrm{ZnFe}_{2} \mathrm{O}_{4}$. Phys B. 2011;406:1989-94.

33. Haber J, Stoch J, Ungier L. X-ray photoelectron spectra of oxygen in oxides of $\mathrm{Co}, \mathrm{Ni}, \mathrm{Fe}$ and $\mathrm{Zn}$. J Electron Spectrosc Relat Phenom. 1976;9:459.

34. Deroubaix G, Marcus P. X-ray photoelectron spectroscopy analysis of copper and zinc oxides and sulphides. Surf Interface Anal 1992;18:39.

35. Thomas M, George KC. Infrared and magnetic study of nanophase zinc ferrite. J Pure Appl Phys Indian. 2009;47:81-6.

36. Wang WP, Yang H, Xian T, Jiang JL. XPS and magnetic properties of $\mathrm{CoFe}_{2} \mathrm{O}_{4}$ nanoparticles synthesized by a polyacrylamide gel route. Mater Trans. 2012;53:1586-9.

37. Biesingera MC, Payne BP, Grosvenord AP, Laua LWM, Gersonb AR, Smart RSC. Resolving surface chemical states in XPS analysis of first row transition metals, oxides and hydroxides: $\mathrm{Cr}, \mathrm{Mn}$, Fe, Co and Ni. Appl Surf Sci. 2011;257:2717-30.

38. de Biasi RS, Cardoso LHG. A simple model for the magnetocrystalline anisotropy in mixed ferrite nanoparticles. Phys B: Condens Matter. 2012;407:3893-96.

39. Aguilera LDS, Marcal RLSB, Campos JB, Silva MHP, Figueiredo ABS. Magnetic filter produced by $\mathrm{ZnFe} 2 \mathrm{O} 4$ nanoparticles using freeze casting. J Mater Res Technol. 2018;7:350-5.

40. Aragon FH, Coaquira JAH, Villegas-Lelovsky L, da Silva SW, Cesar DF, Nagamine LCCM, et al. Evolution of the doping regimes in the Al-doped $\mathrm{SnO} 2$ nanoparticles prepared by a polymer precursor method. J Phys Condens Matter. 2015;27:095301.

41. Gabrielyan L. Effects of iron oxide $\left(\mathrm{Fe}_{3} \mathrm{O}_{4}\right)$ nanoparticles on Escherichia coli antibiotic-resistant strains. J Appl Microbiol. 2019;126:1108-16.

42. Gordon T. Synthesis and characterization of zinc/iron oxide composite nanoparticles and their antibacterial properties. Colloids Surf A Physicochem Eng Asp. 2011;374:1-8.

43. Goya RC, Morais STB, Assis OBG. Evaluation of the antimicrobial activity of chitosan and its quaternized derivative on $E$. coli and S. aureus growth. Braz J Pharmacogn. 2016;26:122-7.

44. Wilkins TD, Holdeman LV, Abramson IJ, Moore WEC. Standardized single-disc method for antibiotic susceptibility testing of anaerobic bacteria. Antimicrob Agents Chemother. 1972;1:451-59.

45. Rufus A, Sreeju N, Philip D. Synthesis of biogenic hematite $(\alpha-$ $\mathrm{Fe} 2 \mathrm{O} 3$ ) nanoparticles for antibacterial and nanofluid applications. RSC Adv. 2016;6:94206-17.

46. Mandal S, Natarajan S, Tamilselvi A, Mayadevi S. Photocatalytic and antimicrobial activities of zinc ferrite nanoparticles synthesized through soft chemical route: a magnetically recyclable catalyst for water/wastewater treatment. J Environ Chem Eng. 2016;4:2706-12.

47. Ashour AH, El-Batal AI, Maksoud, Sayyad GS, Labib SH, Abdeltwab E, et al. Antimicrobial activity of metal-substituted cobalto ferrite nanoparticles synthesized by sol-gel technique. Particuology. 2018;40:141-51.

48. Sharma RP, Raut SD, Mulani RM, Kadam AS, Mane RS. Sol-gel auto-combustion mediated cobalt ferrite nanoparticles: a potential material for antimicrobial applications. Int Nano Lett. 2019;9:141-47.

49. Dmitriev BA, Toukach FV, Holst O, Rietschel ET, Ehlers S. Tertiary structure of Staphylococcus aureus cell wall murein. J Bacteriol. 2004;186:7141-8.

50. Tong SYC, Davis JS, Eichenberger E, Holland TL, Fowler VGJ. Staphylococcus aureus infections: epidemiology, pathophysiology, clinical manifastetions, and management. Clin Microbiol Rev. 2015;28(3):603-61.

51. Boneca IG, Huang ZH, Gage DA, Tomasz A. Characterization of Staphylococcus aureus cell wall glycan strands: evidence for a new beta-N-acetylglucosaminidase activity. J Biol Chem. 2000;275:9910-8.

52. Arakha M, Pal S, Samantarrai D, Panigrahi TK, Mallick BC, Pramanik K, et al. Antimicrobial activity of iron oxide nanoparticle upon modulation of nanoparticle-bacteria interface. Sci Rep. 2015;5:14813.

53. Casbeer E, Sharma VK, LI X-Z. Synthesis and photocalatytic activity of ferrites under visible light: a review. Sep Purif Technol. 2012;87:1-14.

54. Raghunath A, Perumal E. Metal oxide nanoparticles as antimicrobial agents: a promise for the future. Int $\mathbf{J}$ Antimicrob Agents. 2017;49:137-52. 